\title{
Gas-Phase Synthesis and Reactivity of Ligated Group 10 Ions in the Formal +1 Oxidation
}

\section{State}

Kim Greis, ${ }^{(a),(b),(c) ~ I I, ~ Y a n g ~ Y a n g, ~}{ }^{(a)}$ Allan J. Canty, ${ }^{(d)}$ Richard A. J. O’Hair ${ }^{(a) *}$

(a) School of Chemistry and Bio21 Molecular Science and Biotechnology Institute, The University of Melbourne, Parkville, Victoria 3010, Australia

(b) Institut für Chemie, Humboldt-Universität zu Berlin, Brook-Taylor Straße 2, 12489 Berlin, Germany.

(c) Fritz-Haber-Institut der Max-Planck-Gesellschaft, Faradayweg 4-6, 14195 Berlin, Germany

(d) School of Natural Sciences - Chemistry, University of Tasmania, Private Bag 75, Hobart, Tasmania 7001, Australia.

II On leave from Humboldt-Universität zu Berlin. 


\section{Abstract:}

Electrospray ionization of the group 10 complexes [(phen) $\left.\mathrm{M}\left(\mathrm{O}_{2} \mathrm{CCH}_{3}\right)_{2}\right](\mathrm{phen}=1,10$ phenanthroline, $\mathrm{M}=\mathrm{Ni}, \mathrm{Pd}, \mathrm{Pt})$ generates the cations $\left[(\mathrm{phen}) \mathrm{M}\left(\mathrm{O}_{2} \mathrm{CCH}_{3}\right)\right]^{+}$, whose gas-phase chemistry was studied using multistage mass spectrometry experiments in an ion trap mass spectrometer with the combination of collision-induced dissociation (CID) and ion-molecule reactions (IMR). Decarboxylation of $\left[(\text { phen }) \mathrm{M}\left(\mathrm{O}_{2} \mathrm{CCH}_{3}\right)\right]^{+}$under CID conditions generates the organometallic cations $\left[(\mathrm{phen}) \mathrm{M}\left(\mathrm{CH}_{3}\right)\right]^{+}$, which undergo bond homolysis upon a further stage of CID to generate the cations $[(\mathrm{phen}) \mathrm{M}]^{+\bullet}$ in which the metal center is formally in the +1 oxidation state. In the case of $\left[(\text { phen }) \operatorname{Pt}\left(\mathrm{CH}_{3}\right)\right]^{+}$, the major product ion $[(\mathrm{phen}) \mathrm{H}]^{+}$was formed via loss of the metal carbene $\mathrm{Pt}=\mathrm{CH}_{2}$. DFT calculated energetics for the competition between bond homolysis and $\mathrm{M}=\mathrm{CH}_{2}$ loss are consistent with their experimentally observed branching ratios of $2 \%$ and $98 \%$ respectively.

The IMR of [(phen)M $]^{+\bullet}$ with $\mathrm{O}_{2}, \mathrm{~N}_{2}, \mathrm{H}_{2} \mathrm{O}$, acetone and allyl iodide were examined. Adduct formation occurs for $\mathrm{O}_{2}, \mathrm{~N}_{2}, \mathrm{H}_{2} \mathrm{O}$ and acetone. Upon CID, all adducts fragment to regenerate $[(\text { phen }) \mathrm{M}]^{+\bullet}$, except for $\left[(\text { phen }) \operatorname{Pt}\left(\mathrm{OC}\left(\mathrm{CH}_{3}\right)_{2}\right)\right]^{+\bullet}$, which loses a methyl radical to form $\left[(\text { phen }) \mathrm{Pt}\left(\mathrm{OCCH}_{3}\right)\right]^{+}$which upon a further stage of $\mathrm{CID}$ regenerates $\left[(\text { phen }) \mathrm{Pt}\left(\mathrm{CH}_{3}\right)\right]^{+}$via $\mathrm{CO}$ loss. This closes a formal catalytic cycle for the decomposition of acetone into $\mathrm{CO}$ and two methyl radicals with $[(\text { phen }) \mathrm{Pt}]^{+\cdot}$ as catalyst. In the IMR of $[(\text { phen }) \mathrm{M}]^{+\bullet}$ with allyl iodide, formation of $\left[(\text { phen }) \mathrm{M}\left(\mathrm{CH}_{2} \mathrm{CHCH}_{2}\right)\right]^{+}$was observed for all three metals, whereas for $\mathrm{M}=\mathrm{Pt}$ also $[(\text { phen }) \mathrm{Pt}(\mathrm{I})]^{+}$ and $\left[(\text { phen }) \mathrm{Pt}(\mathrm{I})_{2}\left(\mathrm{CH}_{2} \mathrm{CHCH}_{2}\right)\right]^{+}$were observed. Finally, DFT calculated reaction energetics for all IMR reaction channels are consistent with the experimental observations. 


\section{Introduction:}

Complexes of the group 10 metals are widely used as catalysts to facilitate transformations of organic substrates. For example, palladium-catalysed cross-coupling reactions, which form $\mathrm{C}-\mathrm{X}$ bonds ( $\mathrm{X}=\mathrm{C}, \mathrm{N}, \mathrm{O}, \mathrm{S}$ etc.), have revolutionized synthetic chemistry [1]. While oxidation states of 0 and +2 are commonly invoked in the catalytic reactions of these metals, there is growing interest in the chemistry of other oxidation states [2]. The +1 oxidation state of nickel is well established as playing a key role in catalysis [3] and the structural aspects of $\mathrm{Ni}(\mathrm{I})$ complexes have been recently reviewed [4]. While $\mathrm{Pd}(\mathrm{I})$ and $\mathrm{Pt}(\mathrm{I})$ binuclear complexes are known $[2,5]$, only recently has the monomeric $\mathrm{Pd}(\mathrm{I})$ complex $\left[\mathrm{Pd}\left(\mathrm{P} t \mathrm{Bu}_{3}\right)_{2}\right]\left[\mathrm{PF}_{6}\right]$ been isolated and shown to catalyse the oxidative cross-coupling of arylantimony and arylboron nucleophiles [6]. With the resurgence of photoredox chemistry in organic synthesis, $\mathrm{Ni}(\mathrm{I})$ complexes are often invoked as key intermediates in catalytic cycles $[7-10]$.

Mass spectrometry based techniques have been developed over the past 50 years to provide fundamental structural, mechanistic and energetic information about intermediates and reactions associated with metal mediated processes [11-14]. Professor Schwarz has been one of the key pioneers in this area, where he has shed light on mechanistic aspects of $\mathrm{C}-\mathrm{H}$ bond activation in methane $[15,16]$ and developed a number of important concepts including "remote functionalization" [17] and "two state reactivity" [18]. Gas-phase studies can provide powerful insights into catalytic cycles since they reveal details on elementary steps that can be difficult to study under typical conditions used for catalysis $[19,20]$. While the gas-phase chemistry of bare monoatomic group 10 cations has been extensively studied by Schwarz [21, 22], Armentrout [23$25]$ and others [26], previous work on the reactions of $\left[\left(\left(\mathrm{C}_{6} \mathrm{H}_{5}\right)_{3} \mathrm{P}\right)_{\mathrm{n}} \mathrm{Au}\right]^{+}$with phenyl iodide has shown that ligation can have a profound effect on reactivity, with the bare cation $(n=0)$ undergoing a range of reactions, the monoligated $(n=1)$ complex selectively undergoing $C$-I bond activation and the bisligated complex $(n=2)$ being unreactive [27]. Thus, we were interested in developing a gasphase synthesis of ligated group 10 cations in the formal oxidation state of +1 . We chose the $\left[(\text { phen }) \mathrm{M}\left(\mathrm{O}_{2} \mathrm{CCH}_{3}\right)\right]^{+}$complexes as suitable precursors since: the 1,10-phenanthroline (phen) ligand has been widely used in condensed phase synthetic and catalytic studies [28]; our previous work has shown that these complexes are readily generated via ESI-MS and readily fragment via decarboxylation [29] to generate organometallic cations, [(phen) $\left.\mathrm{M}\left(\mathrm{CH}_{3}\right)\right]^{+}$, which undergo a number of interesting reactions of relevance to catalysis [30-35]; CID of related cations suggest that bond homolysis should occur [36]. Here we examine the use of bond homolysis reactions of 
$\left[(\text { phen }) \mathrm{M}\left(\mathrm{CH}_{3}\right)\right]^{+}$to generate the cations $[(\mathrm{phen}) \mathrm{M}]^{+\bullet}$ for subsequent ion-molecule reaction studies with background water, $\mathrm{O}_{2}$ and $\mathrm{N}_{2}$ and the reagents acetone and allyl iodide. This approach is complementary to that of Parker and Gronert, who generated the ligated nickel radical cations $\left[(\text { phen })_{n} \mathrm{Ni}\right]^{+\bullet}(\mathrm{n}=1$ and 2$)$ via electron transfer dissociation (ETD) to the dication $\left[(\mathrm{phen})_{2} \mathrm{Ni}\right]^{2+}$ [37].

\section{Experimental}

Chemicals from the following suppliers were used without further purification: (i) Merck: methanol (HPLC grade for ESI/MS ${ }^{n}$ experiments); (ii) Chem-Supply: acetone (AR grade); (iii) Cambridge Isotope Laboratories: acetone-d6; (iv) Sigma-Aldrich: allyl iodide.

While the precursors $\left[(\right.$ phen $\left.) \mathrm{Ni}\left(\mathrm{O}_{2} \mathrm{CCH}_{3}\right)_{2}\right]$ and $\left[(\right.$ phen $\left.) \mathrm{Pd}\left(\mathrm{O}_{2} \mathrm{CCH}_{3}\right)_{2}\right]$ were available from a previous study [32], [(phen) $\left.\mathrm{Pt}\left(\mathrm{O}_{2} \mathrm{CCH}_{3}\right)_{2}\right]$ was synthesized via a literature procedure [38-40].

\section{Mass spectrometry Experiments:}

Mass spectrometric experiments were conducted on a Thermo Scientific linear ion trap (LTQ) spectrometer modified to allow IMR studies to be undertaken [41, 42]. It has been demonstrated that collisions with the helium bath gas quasi-thermalize ions to room temperature under IMR conditions [43].

The organometallic acetate cations, $\left[(\text { phen }) \mathrm{M}\left(\mathrm{O}_{2} \mathrm{CCH}_{3}\right)\right]^{+}$, were generated via direct electrospray ionization $(\mathrm{ESI})$ of the acetate complexes $\left[(\mathrm{phen}) \mathrm{M}\left(\mathrm{O}_{2} \mathrm{CCH}_{3}\right)_{2}\right]$ dissolved in methanol $(\sim 0.1 \mathrm{mM})$. The analyte solution was injected into the ESI source at a flow rate of $10 \mu \mathrm{L} / \mathrm{min}$. ESI conditions used were: spray voltage $4.0 \mathrm{kV}$; capillary temperature $300{ }^{\circ} \mathrm{C}$; nitrogen sheath gas flow rate ca. 10 arbitrary units. The three-coordinate organometallic cations, $\left[(\text { phen }) \mathrm{M}\left(\mathrm{CH}_{3}\right)\right]^{+}$, were generated by low-energy CID of the mass-selected complexes, $\left[(\text { phen }) \mathrm{M}\left(\mathrm{O}_{2} \mathrm{CCH}_{3}\right)\right]^{+}$, in the linear ion trap. Lowenergy CID on the mass-selected $\left[(\text { phen }) \mathrm{M}\left(\mathrm{CH}_{3}\right)\right]^{+}$can be used to generate the two-coordinate organometallic cations, $[(\text { phen }) \mathrm{M}]^{+\bullet}$. The helium bath gas was used as the collision gas and the CID conditions used included: a $\mathrm{Q}$ value of 0.25 ; an excitation time of $30 \mathrm{~ms}$, with the normalized 
collisional energy varied from 0.3-1.1 V. IMR of the mass-selected organometallic cations, $[(\text { phen }) \mathrm{M}]^{+\bullet}$, and acetone were carried out in a series of $\mathrm{MS}^{4}$ experiments with a reaction time of $100 \mathrm{~ms}$. Acetone was introduced in the ion trap at a flow rate of $10 \mu \mathrm{L} / \mathrm{h}$ for the reactions with the Ni and Pd cations and $100 \mu \mathrm{L} / \mathrm{h}$ for the Pt cations. IMR between $[(\text { phen }) \mathrm{M}]^{+\bullet}$ and allyl iodide were carried out with a reaction time of $30 \mathrm{~ms}$. Allyl iodide was introduced at a flow rate of $50 \mu \mathrm{L} / \mathrm{h}$. Distinction between complexes with similar mass-to-charge ratios such as $\left[(\mathrm{phen})^{60} \mathrm{Ni}_{(\mathrm{CH}}\left(\mathrm{CH}_{3}\right]^{+}\right.$and $\left[(\text { phen }){ }^{58} \mathrm{Ni}(\mathrm{OH})\right]^{+}$was achieved by selection of single isotope mass spectra $\left({ }^{58} \mathrm{Ni},{ }^{106} \mathrm{Pd}\right.$ and $\left.{ }^{195} \mathrm{Pt}\right)$.

\section{Computational Methods:}

Structures of all reactants, transition states and intermediates were fully optimized using the software Gaussian 09 [44]. If not stated otherwise, the M06 DFT functional [45] employing the SDD effective core potentials (ECPs) for Pt, Pd and Ni [46, 47] and the 6-31G(d) basis set for all other atoms were used [48]. Some structures were reoptimized using Gaussian16 [49] and the B3LYP DFT functional [50] with Grimme's D3 correction [51, 52] with the basis set SDD for Pt, $\mathrm{Pd}$ and $\mathrm{Ni}$ and the 6-311G(d) basis set for all other atoms [53]. Vibrational frequency calculations were performed to confirm stationary as minima (no imaginary frequency) or transition states (one imaginary frequency) and to obtain the zero-point energy (ZPE) corrections. Each transition state was connected to two minima by intrinsic reaction coordinate (IRC) calculations. A series of single point energy calculations were carried out using the ORCA suite of programs [54] using the semiempirical hybrid functional $\omega$ B97X-D3 [55] and double hybrid functionals PWPB95-D3 [56] and DSDPBEP86-D3 [57], with the RI approximation [58] on the MP2 part of the calculation, with the basis set def2-TZVPP and ECPs on Pd and Pt [59]. Semi-empirical double-hybrid functionals have been chosen over non-empirical ones, because the former have been shown to be more robust [60]. The optimized structures with the B3LYP-D3/6-311G(d) level of theory were used for the single point energy calculations 
The thermodynamic parameter used to determine the likelihood of low-pressure uni- and bimolecular reactions to proceed was the reaction energy, $\triangle(E+Z P E)$. The precursor ions undergo multiple collisions with the helium bath gas resulting in slow "heating" until fragmentation occurs, in the case of low energy CID [61]. Thus, the effective temperature is not known and will be different for each system. For the IMR, Dau et al have highlighted that the relevant thermodynamic parameter to use for low-pressure bimolecular reactions is the reaction energy rather than the Gibbs free energy due to the unfavorable entropy arising from loss of degrees of freedom in the entrance channel where two gas-phase molecules react to form a single encounter complex [62].

With regards to the multiplicities of the organometallic cations, $\left[(\text { phen }) \mathrm{M}\left(\mathrm{CH}_{3}\right)\right]^{+}$, we found that the ground states are singlets in the case of $\mathrm{Pd}$ and $\mathrm{Pt}$, but that the ground state of $\left[(\mathrm{phen}) \mathrm{Ni}\left(\mathrm{CH}_{3}\right)\right]^{+}$is a triplet. This is consistent with the related $\left[(\text { bipy }) \mathrm{M}\left(\mathrm{CH}_{3}\right)\right]^{+}$cations, where the ground state is a singlet for Pd and Pt and a triplet for Ni [63].

\section{Results and Discussion}

\subsection{Bond Homolysis vs. Carbene Formation}

Electrospray ionization of $\left[(\mathrm{phen}) \mathrm{M}\left(\mathrm{O}_{2} \mathrm{CCH}_{3}\right)_{2}\right](\mathrm{M}=\mathrm{Ni}, \mathrm{Pd}, \mathrm{Pt})$ complexes dissolved in methanol in the positive ion mode results in the formation of the mononuclear cationic complexes $\left[(\text { phen }) \mathrm{M}\left(\mathrm{O}_{2} \mathrm{CCH}_{3}\right)\right]^{+}$. CID of these mass-selected complexes results in the formation of the methyl complexes [(phen) $\left.\mathrm{M}\left(\mathrm{CH}_{3}\right)\right]^{+}$as previously described (Fig. S1, eq. 1) [31, 33]. Besides decarboxylation, acetoxyl loss is another channel for $\mathrm{M}=\mathrm{Ni}, \mathrm{Pd}$, resulting in the formation of the cationic complexes, $[(\text { phen }) \mathrm{M}]^{+\bullet}$, where the metal is formally in the oxidation state +1 (eq. 2 ). As noted previously [30] the remaining ions observed in the mass spectra arise from IMR between the fragment ions and the background gases $\mathrm{H}_{2} \mathrm{O}, \mathrm{N}_{2}$ and $\mathrm{O}_{2}$. Thus, the complexes $\left[(\right.$ phen $) \mathrm{M}_{\left.\left(\mathrm{CH}_{3}\right)\right]^{+}}$ form adducts with water and dinitrogen for $\mathrm{M}=\mathrm{Pt}$ (eq. 3). [(phen) $\left.\mathrm{Ni}\left(\mathrm{CH}_{3}\right)\right]^{+}$undergoes hydrolysis rather than adduct formation, resulting in the formation of $[(\text { phen }) \mathrm{Ni}(\mathrm{OH})]^{+}$(eq. 4). For $\mathrm{M}=\mathrm{Ni}$, $[(\text { phen }) \mathrm{M}]^{+\bullet}$ forms adducts with water and dioxygen (eq. 5). 


$\begin{array}{llll}{\left[(\text { phen }) \mathrm{M}\left(\mathrm{O}_{2} \mathrm{CCH}_{3}\right)\right]^{+}} & \rightarrow & {\left[(\text { phen }) \mathrm{M}\left(\mathrm{CH}_{3}\right)\right]^{+}+\mathrm{CO}_{2}} & (\mathrm{M}=\mathrm{Ni}, \mathrm{Pd}, \mathrm{Pt}) \\ {\left[(\text { phen }) \mathrm{M}\left(\mathrm{O}_{2} \mathrm{CCH}_{3}\right)\right]^{+}} & \rightarrow & {[(\text { phen }) \mathrm{M}]^{+\bullet}+\mathrm{CH}_{3} \mathrm{CO}_{2} \bullet \quad(\mathrm{M}=\mathrm{Ni}, \mathrm{Pd})} \\ {\left[(\text { phen }) \mathrm{M}\left(\mathrm{CH}_{3}\right)\right]^{+}+\mathrm{L}} & & \rightarrow & {\left[(\text { phen }) \mathrm{M}\left(\mathrm{CH}_{3}\right)(\mathrm{L})\right]^{+}} \\ {\left[(\text {phen }) \mathrm{Ni}\left(\mathrm{CH}_{3}\right)\right]^{+}+\mathrm{H}_{2} \mathrm{O}} & & \rightarrow & {[(\text { phen }) \mathrm{Ni}(\mathrm{OH})]^{+}+\mathrm{CH}_{4}} \\ {[(\text { phen }) \mathrm{M}]^{+\bullet}+\mathrm{L}} & & \rightarrow & {[(\text { phen }) \mathrm{M}(\mathrm{L})]^{+\bullet}}\end{array}$

Upon CID the mass-selected complexes $\left[(\text { phen }) \mathrm{M}\left(\mathrm{CH}_{3}\right)\right]^{+}$lose a methyl radical to form $[(\text {phen }) \mathrm{M}]^{+\bullet}$ (Fig. 1, eq. 6). However, for $\mathrm{M}=\mathrm{Pt}$, the loss of a methyl radical is only a minor pathway. The major pathway is the loss of $\mathrm{Pt}=\mathrm{CH}_{2}$ to generate the protonated ligand phenanthroline $[(\mathrm{phen}) \mathrm{H}]^{+}$ $(\mathrm{m} / \mathrm{z}$ 181, eq. 7), which is detected in the mass spectrum (Fig. 1c). Butschke and Schwarz reported a related reaction in the $\mathrm{CID}$ of $\left[(\text { bipy }) \mathrm{Pt}\left(\mathrm{CH}_{3}\right)\right]^{+}[63]$. The organometallic cation $\left[(\text { phen) } \mathrm{Pt}]^{+\bullet}\right.$ (eq. 6) and the carbene $\mathrm{Pt}=\mathrm{CH}_{2}$ (eq. 7) are formed with branching ratios of $2 \%$ and $98 \%$ respectively. Although the thermochemistry of the neutral metal carbenes is not known for all group 10 metals, the $\mathrm{Pt}=\mathrm{CH}_{2}$ bond dissociation energy has been determined to be $446 \mathrm{~kJ} \mathrm{~mol}^{-1}$ [64], which highlights that it is a particularly stable species.

$\begin{array}{lll}{\left[(\text { phen }) \mathrm{M}\left(\mathrm{CH}_{3}\right)\right]^{+}} & \rightarrow & {[(\text { phen }) \mathrm{M}]^{+\bullet}+\cdot \mathrm{CH}_{3}} \\ {\left[(\text { phen }) \mathrm{M}\left(\mathrm{CH}_{3}\right)\right]^{+}} & \rightarrow & {[(\text { phen }) \mathrm{H}]^{+}+\mathrm{M}=\mathrm{CH}_{2}}\end{array}$

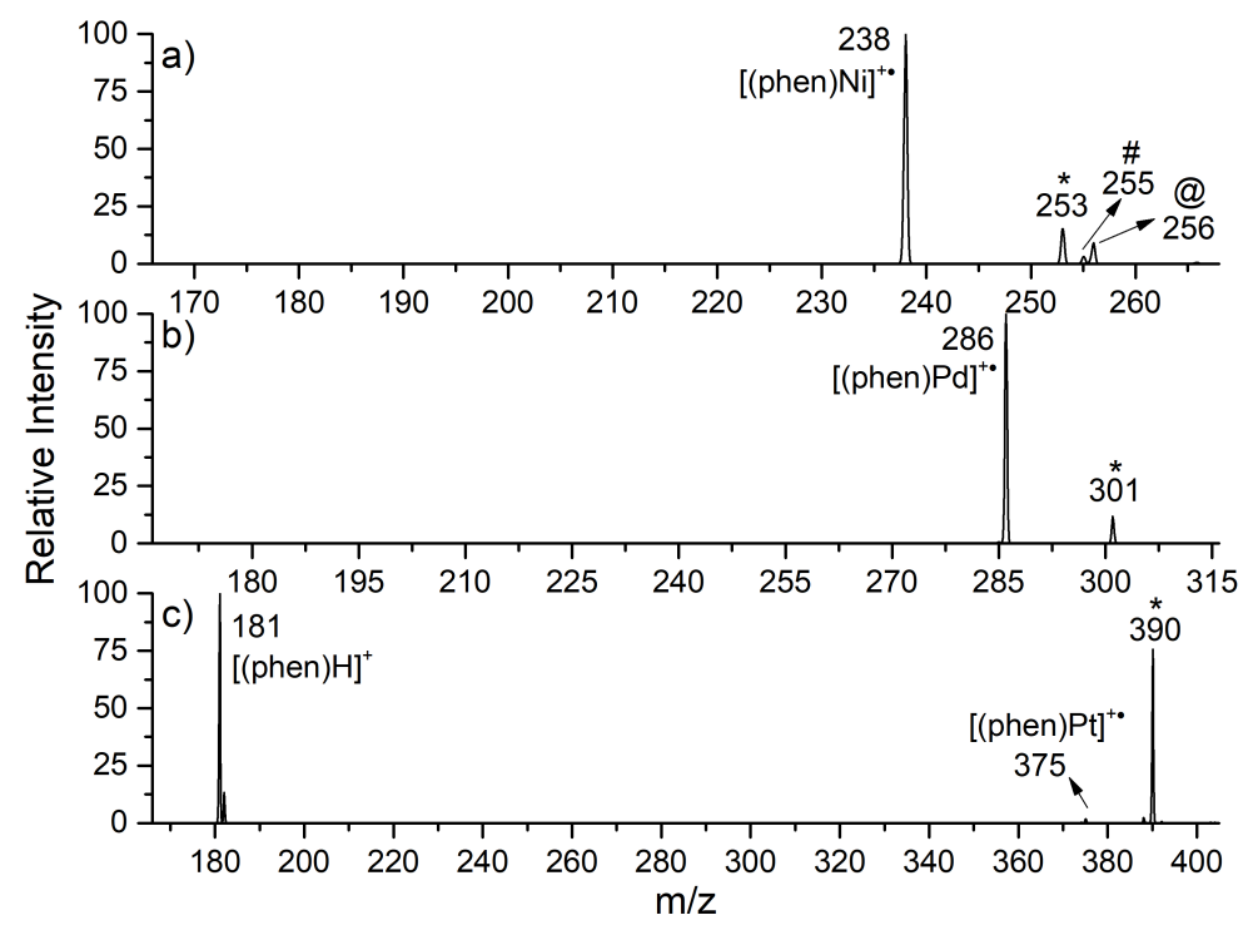

Fig. 1 LTQ $\mathrm{MS}^{3}$ spectra of mass-selected precursor ions, [(phen) $\left.\mathrm{M}\left(\mathrm{CH}_{3}\right)\right]^{+}$undergoing $\mathrm{CID}$ at a normalized collision energy of 13 for $\mathrm{M}=\mathrm{Ni}, \mathrm{Pd}$ and 20 for $\mathrm{M}=\mathrm{Pt}$ (arbitrary units) in the linear 
ion trap: (a) $\mathrm{M}=\mathrm{Ni}$; (b) $\mathrm{M}=\mathrm{Pd}$; and (c) $\mathrm{M}=\mathrm{Pt}$. The mass-selected precursor ions are designated by *, while \# represents the hydrolysis product (eq. 4). The symbol @ designates the water adduct of $[(\text { phen }) \mathrm{Ni}]^{+\bullet}$ (eq. 5)

To better understand the competing fragmentation pathways for $\left[(\text { phen }) \mathrm{M}\left(\mathrm{CH}_{3}\right)\right]^{+}$, DFT calculations have been performed to compare the energetics for bond homolysis to form $[(\text { phen }) \mathrm{M}]^{+\bullet}$ (eq. 6) relative to the barrier heights associated with formation of the metal carbene, $\mathrm{M}=\mathrm{CH}_{2}$ (eq. 7). Bond homolysis is a barrierless process, whereas the formation of $\mathrm{M}=\mathrm{CH}_{2}$ requires surmounting a transition state, in which a hydrogen from the methyl group translocates to the nitrogen of phenanthroline to form an intermediate, $\left[(\text { phen }) \mathrm{H}\left(\mathrm{M}=\mathrm{CH}_{2}\right)\right]^{+}$, where the $\mathrm{M}=\mathrm{CH}_{2}$ moiety is bound coordinatively to the protonated ligand, before dissociation. For every metal the singlet state has been considered and for nickel also the triplet state was considered, because the triplet precursor ion is $25 \mathrm{~kJ} \mathrm{~mol}^{-1}$ more stable than in its singlet state. The respective barriers are compared in a potential energy diagram (Fig. 2). The trends are consistent with experiment: going down group 10 the bond homolysis is disfavored whereas metal carbene formation becomes favored. Furthermore, among the singlet transition states, the one for formation of $\mathrm{Pt}=\mathrm{CH}_{2}$ is the lowest. The transition state for the triplet nickel is the lowest, but the energy of the bond homolysis still lies substantially below. However, even if the trends are in agreement with the experiment that bond homolysis occurs for nickel and palladium, but carbene formation is preferred for platinum, both the thermodynamics and the kinetics for the competing reaction are not consistent with experiment for the case of platinum. Thus, with the B3LYP-D3/SDD 6-311G(d) level of theory, the bond homolysis requires less energy than forming the transition state and is energetically favored over the formation of protonated phenanthroline and carbene for all the metals. To probe this further, a series of single point calculations with higher levels of theory has been carried out for platinum. Single point energy calculations have been carried out on the structures that were optimized with the B3LYP-D3/SDD 6-311G(d) level of theory with the functionals $\omega$ B97X-D3, PWPB95-D3 and DSD-PBEP86-D3 and the basis set def2-TZVPP for all atoms. These functionals have shown to be very robust in past studies [60]. The relevant energetics obtained with these functionals for Pt are given in Table 1 while the potential energy diagrams are given in Fig. S2. With the functionals WB97X-D3 and PWPB95-D3 the overall energetics for the observed formation of $\mathbf{5}+[(\text { phen }) \mathrm{H}]^{+}$are thermodynamically favored over bond homolysis to give $\mathbf{3}+\cdot \mathrm{CH}_{3}$, while for the functional DSD-PBEP86-D3 the energetics are both kinetically and thermodynamically favored for $\mathrm{Pt}=\mathrm{CH}_{2}$ formation. The best results are given by both double hybrid functionals PWPB95-D3 and DSD-PBP86-D3, which are expected to perform better than common hybrid DFT functionals 
[65]. Chen has previously noted that theory performs better for the energetics of rearrangement reactions in related ligated $\mathrm{Pd}$ cations than for bond homolysis [36].

Table 1 DFT calculated reaction energetics (in $\left.\mathrm{kJ} \mathrm{mol}^{-1}\right)$ for fragmentation of $\left[(\text { phen }) \mathrm{Pt}\left(\mathrm{CH}_{3}\right)\right]^{+}$via competing bond homolysis pathway (giving $\mathbf{3}+\cdot \mathrm{CH}_{3}$ ) and $\mathrm{Pt}=\mathrm{CH}_{2}$ pathway.

\begin{tabular}{|c|c|c|c|c|}
\hline Level of theory & $3+\cdot \mathrm{CH}_{3}$ & $\mathbf{T S}_{2-4}$ & 4 & $\mathbf{5}+[(\text { phen }) \mathrm{H}]^{+}$ \\
\hline $\begin{array}{c}\text { M06/SDD } \\
6-31 G(d)\end{array}$ & +258 & +291 & +112 & +255 \\
\hline $\begin{array}{c}\text { B3LYP/SDD } \\
6-31 G(d)\end{array}$ & +252 & +293 & +107 & +240 \\
\hline $\begin{array}{c}\text { B3LYP-D3/SDD } \\
6-31 G(d)\end{array}$ & +268 & +292 & +112 & +275 \\
\hline $\begin{array}{c}\text { B3LYP-D3/SDD } \\
6-311 \mathrm{G}(\mathrm{d})\end{array}$ & +261 & +292 & +112 & +270 \\
\hline $\begin{array}{c}\omega \mathrm{B} 97 \mathrm{X}-\mathrm{D} 3 / \text { def2- } \\
\text { TZVPP }^{\text {(a) }}\end{array}$ & +289 & +322 & +135 & +284 \\
\hline $\begin{array}{c}\text { PWPB95-D3/def2- } \\
\text { TZVPP }^{\text {(a) }}\end{array}$ & +305 & +312 & +123 & +279 \\
\hline $\begin{array}{c}\text { DSD-PBEP86- } \\
\text { D3/def2-TZVPP (a) }\end{array}$ & +310 & +306 & +104 & +277 \\
\hline
\end{tabular}

(a) Data is only $\Delta E$ since frequency calculations are too expensive for these functionals 


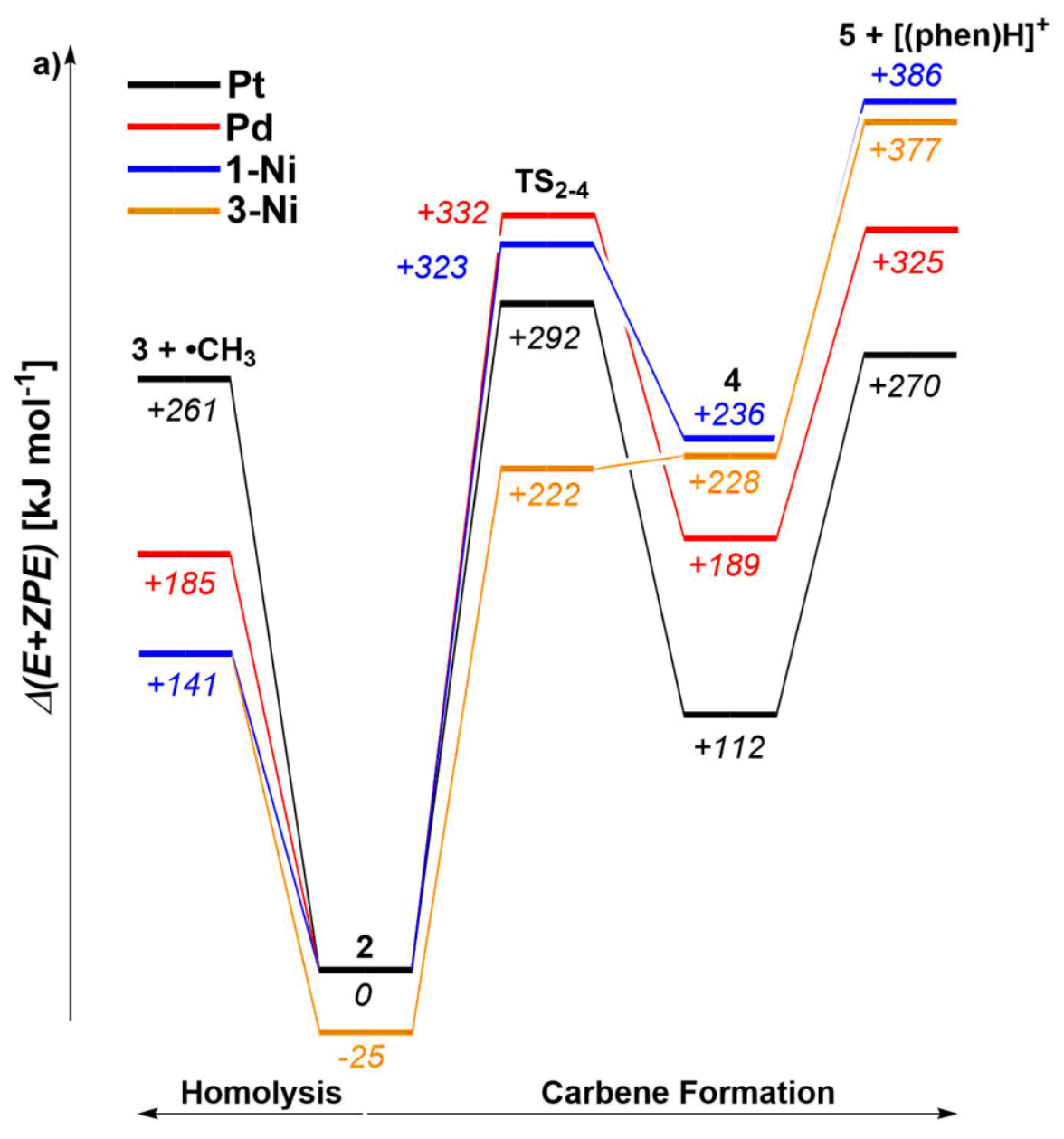<smiles>CCN1C=CC=C2C=CC3=CC=CN4CN2C1=C34</smiles>

2<smiles></smiles>

$\mathrm{TS}_{2-4}$<smiles></smiles>

3

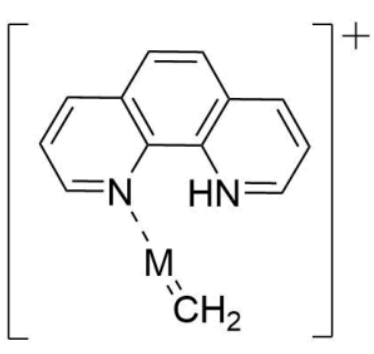

4

$\mathrm{M}=\mathrm{CH}_{2}$

5

Fig. 2 Results of DFT calculations at B3LYP-D3/SDD 6-311G(d) level of theory. (a) Plot of the potential energy diagram for both pathways of dissociation of $\left[(\mathrm{phen}) \mathrm{M}\left(\mathrm{CH}_{3}\right)\right]^{+}$with $\mathrm{M}=1-\mathrm{Ni}$ (blue), 3-Ni (orange), Pd (red) and Pt (black); (b) Structures of key species 
A key question regarding the $[(\mathrm{phen}) \mathrm{M}]^{+\bullet}$ metal complexes is whether they are in the +1 oxidation or +2 oxidation state (i.e. where the phen ligand is a redox non-innocent ligand [66]). An examination of the DFT calculated spin density at the metal centers in the $[(\text { phen }) \mathrm{M}]^{+\bullet}$ metal complexes reveals (Table S1) that they range from $94.7 \%$ for $\mathrm{M}=\mathrm{Ni}$ to $77.8 \%$ for $\mathrm{M}=\mathrm{Pt}$. This suggests that the complexes can be regarded as being in the +1 oxidation state and that the phen ligand largely behaves as a redox innocent ligand.

\subsection{IMR with the Background Gases $\mathrm{O}_{2}, \mathrm{~N}_{2}$ and $\mathrm{H}_{2} \mathrm{O}$.}

Water and dinitrogen are always present in the ion trap and readily react with three-coordinate metal complexes to form adducts (eq. 3) [30]. The two-coordinate metal complexes, [(phen)M] ${ }^{+}$ react with background water, dinitrogen and dioxygen to form adducts (eq. 5, Fig. 3). When $\mathrm{M}=$ $\mathrm{Ni}$, mainly water and dioxygen adducts are formed, whereas only a minor peak can be observed for dinitrogen adduct formation. For $\mathrm{M}=\mathrm{Pd}$, adduct formation only occurs to a minor degree with water and dioxygen. For $\mathrm{M}=\mathrm{Pt}$, adduct formation readily occurs for the three background gases, the water and dinitrogen adduct being favored over dioxygen adduct formation.

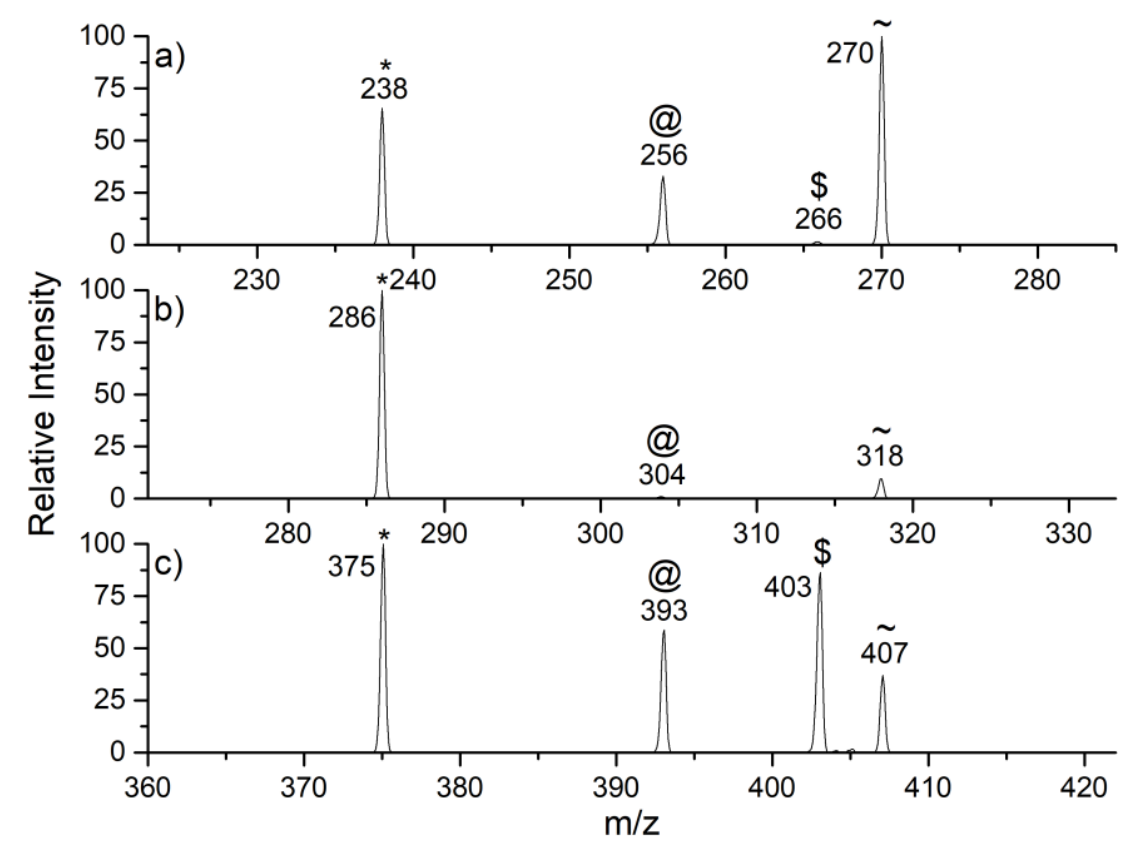

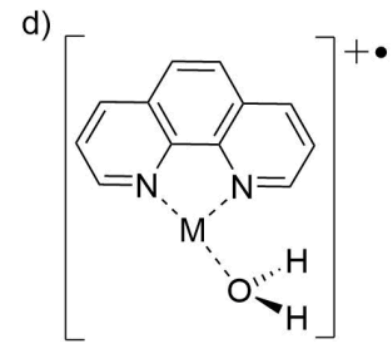

6

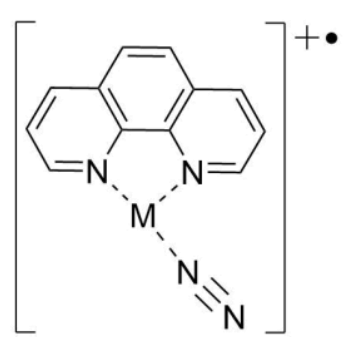

7

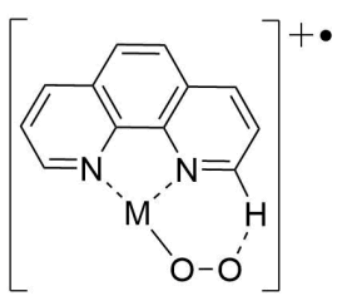

$8 \mathbf{a}$

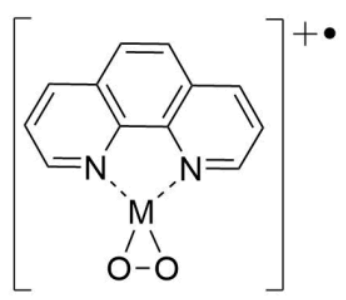

$8 b$ 
Fig. 3 (a-c) LTQ MS ${ }^{4}$ spectra of mass-selected precursor ions, [(phen)M] ${ }^{+\bullet}$, undergoing IMR at an activation time of $100 \mathrm{~ms}$ with background gases present in the linear ion trap: (a) $\mathrm{M}=\mathrm{Ni}$; (b) $\mathrm{M}=$ $\mathrm{Pd}$; and (c) $\mathrm{M}=\mathrm{Pt}$. The mass-selected precursor ions are designated by *, while @, \$ and represent the water, the dinitrogen and the dioxygen adducts respectively (eq. 5); (d) Structures of key species calculated at the M06/SDD 6-31G(d) level of theory

Table 2 DFT calculated reaction energetics of forming the water, dinitrogen and dioxygen adducts of $[(\text { phen }) \mathrm{M}]^{+\bullet}(\mathrm{M}=\mathrm{Ni}, \mathrm{Pd}, \mathrm{Pt})$ with $\mathrm{M06/SDD}$ 6-31G(d) level of theory

\begin{tabular}{|c|c|c|c|c|}
\hline $\begin{array}{c}\Delta(E+Z P E)[\mathrm{kJ} \\
\left.\mathrm{mol}^{-1}\right]\end{array}$ & $\mathrm{H}_{2} \mathrm{O}$ & $\mathrm{N}_{2}$ & $\begin{array}{c}\mathrm{O}_{2} \text { (end-on) } \\
\mathbf{( 8 a )}\end{array}$ & $\begin{array}{c}\mathrm{O}_{2} \text { (side-on) } \\
(\mathbf{8 b})\end{array}$ \\
\hline $\mathrm{Ni}$ & -139 & -95 & -234 & -296 \\
\hline $\mathrm{Pd}$ & -112 & -72 & -229 & -275 \\
\hline $\mathrm{Pt}$ & -137 & -115 & -269 & -348 \\
\hline
\end{tabular}

The structures and energetics of adduct formation for each metal of the cation $[(\mathrm{phen}) \mathrm{M}]^{+\bullet}$ have been calculated at the M06/SDD 6-31G(d) level of theory (Fig. 3d, Table 2). In the case of water and dinitrogen an end-on fashioned binding mode is preferred. For dioxygen two stable isomers have been found: one where dioxygen binds in an end-on and one where it binds in a side-on fashion, the latter being favored over the former thermodynamically. Overall, the thermodynamics for adduct formation of each background gas with each metal are favorable and follow the order Pt $>\mathrm{Ni}>\mathrm{Pd}$, which is consistent with more abundant adduct formation observed in the cases of Pt and Ni (Figs. 3c and 3a) over that of Pd (Fig. 3b).

\subsection{IMR with Acetone}

The metal cations, $[(\text { phen }) \mathrm{M}]^{+\bullet}$, form the adducts, $\left[(\text { phen }) \mathrm{M}\left(\mathrm{OC}\left(\mathrm{CH}_{3}\right)_{2}\right)\right]^{+\bullet}$, with acetone in IMR (eq. 8, Fig. 4). In the case of Pt, a minor ion is observed at $\mathrm{m} / \mathrm{z} 418$, which corresponds to loss of a methyl radical from the acetone adduct (eq. 9). The fact that an analogous peak is not observed in the case of acetone- $\mathrm{d}_{6}$ may be due to the operation of an isotope effect [67]. 


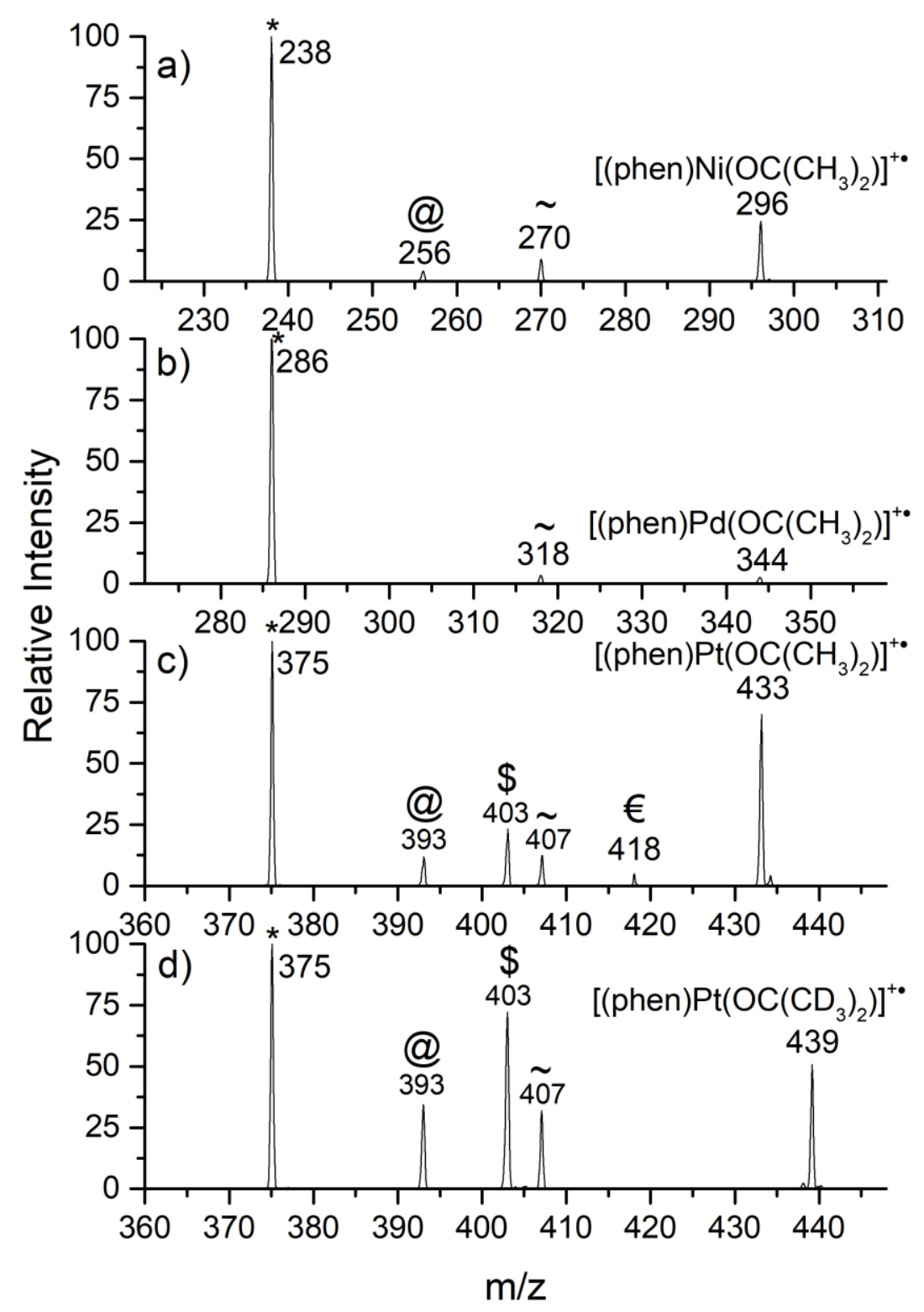

Fig. 4 LTQ MS ${ }^{4}$ spectra of mass-selected precursor ions, $[(\text { phen }) \mathrm{M}]^{+*}$, undergoing IMR at an activation time of $100 \mathrm{~ms}$ with acetone (a-c) and acetone- $\mathrm{d}_{6}(\mathrm{~d})$ in the linear ion trap: (a) $\mathrm{M}=\mathrm{Ni}$;

(b) $\mathrm{M}=\mathrm{Pd}$; and (c-d) M = Pt. The mass-selected precursor ions are designated by *, while @ , \$ and $\sim$ are representing the water, the dinitrogen and the dioxygen adducts respectively (eq. 5). The symbol $€$ represents the acyl complex that is formed via eq. 10

$\begin{array}{lllll}{[(\text { phen }) \mathrm{M}]^{+\bullet}} & + & \mathrm{OC}\left(\mathrm{CH}_{3}\right)_{2} & \rightarrow & {\left[(\text { phen }) \mathrm{M}\left(\mathrm{OC}\left(\mathrm{CH}_{3}\right)_{2}\right)\right]^{+\bullet}} \\ {[(\text { phen }) \mathrm{Pt}]^{+\bullet}+} & \mathrm{OC}\left(\mathrm{CH}_{3}\right)_{2} & \rightarrow & {\left[(\text { phen }) \mathrm{Pt}\left(\mathrm{OCCH}_{3}\right)\right]^{+}+\cdot \mathrm{CH}_{3}}\end{array}$ 
Upon CID, the acetone adducts dissociate to regenerate $[(\text { phen }) \mathrm{M}]^{+\bullet}$ in the case of $\mathrm{M}=\mathrm{Ni}, \mathrm{Pd}$ (eq. 10). For $\mathrm{M}=\mathrm{Pt}$, the dissociation is only a minor pathway compared to the loss of a methyl radical to form the acyl complex [(phen) $\left.\mathrm{Pt}\left(\mathrm{OCCH}_{3}\right)\right]^{+}$(eq. 11, Fig. 5, m/z 418). The loss of methyl (15 Da) was confirmed by deuterium labeling experiments with fully deuterated acetone, where a mass loss of $18 \mathrm{Da}$ was observed. The differences in branching ratios for $\mathrm{OC}\left(\mathrm{CH}_{3}\right)_{2}(\mathrm{BR}$ eq. $10=19.5 \%)$ versus $\mathrm{OC}\left(\mathrm{CD}_{3}\right)_{2}(\mathrm{BR}$ eq. $10=42.5 \%)$ and for $\cdot \mathrm{CH}_{3}(\mathrm{BR}$ eq. $11=70.2 \%)$ versus $\cdot \mathrm{CD}_{3}$ (BR eq. 11 $=45.6 \%)$ losses suggest that an isotope effect operates for the $\mathrm{C}-\mathrm{C}$ bond cleavage step associated with methyl radical loss [67].

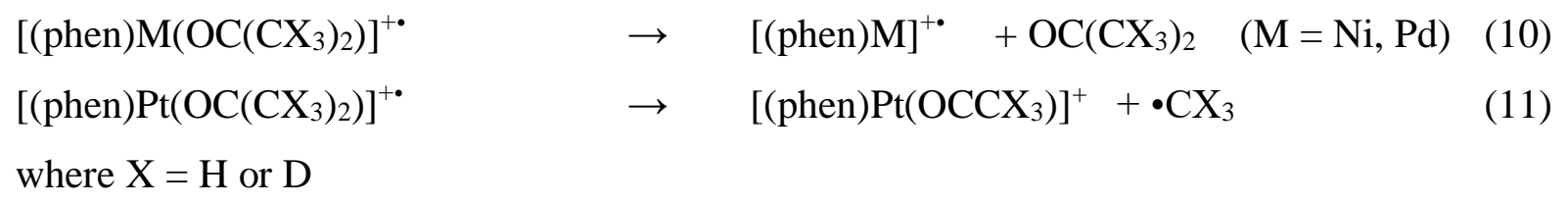

Upon further CID the acyl complex $\left[(\text { phen }) \mathrm{Pt}\left(\mathrm{OCCH}_{3}\right)\right]^{+}(\mathrm{m} / z$ 418) loses $\mathrm{CO}$ to regenerate the three-coordinate methyl complex $\left[(\text { phen }) \operatorname{Pt}\left(\mathrm{CH}_{3}\right)\right]^{+}$(eq. 12, $\mathrm{m} / \mathrm{z}$ 390). In the deuterium labeling experiments, the same complex was generated with a fully deuterated methyl ligand (Fig. S3). Thus, $[(\text { phen }) \mathrm{Pt}]^{+}$. catalyses, in contrast to the nickel and palladium complexes, formally the decomposition of acetone into $\mathrm{CO}$ and two methyl radicals (eq. 13, Scheme 1). Although photolysis or thermolysis of acetone gives a range of products, $\mathrm{C}-\mathrm{C}$ bond homolysis to give methyl radicals is a key channel [68, 69].

\begin{tabular}{|c|c|c|}
\hline$\left[(\text { phen }) \operatorname{Pt}\left(\mathrm{OCCH}_{3}\right)\right]^{+}$ & $\rightarrow$ & {$\left[(\text { phen }) \operatorname{Pt}\left(\mathrm{CH}_{3}\right)\right]^{+}$} \\
\hline$\left(\mathrm{CH}_{3}\right)_{2} \mathrm{CO}$ & $\rightarrow$ & $\mathrm{CO}+2 \cdot \mathrm{CH}_{3}$ \\
\hline
\end{tabular}




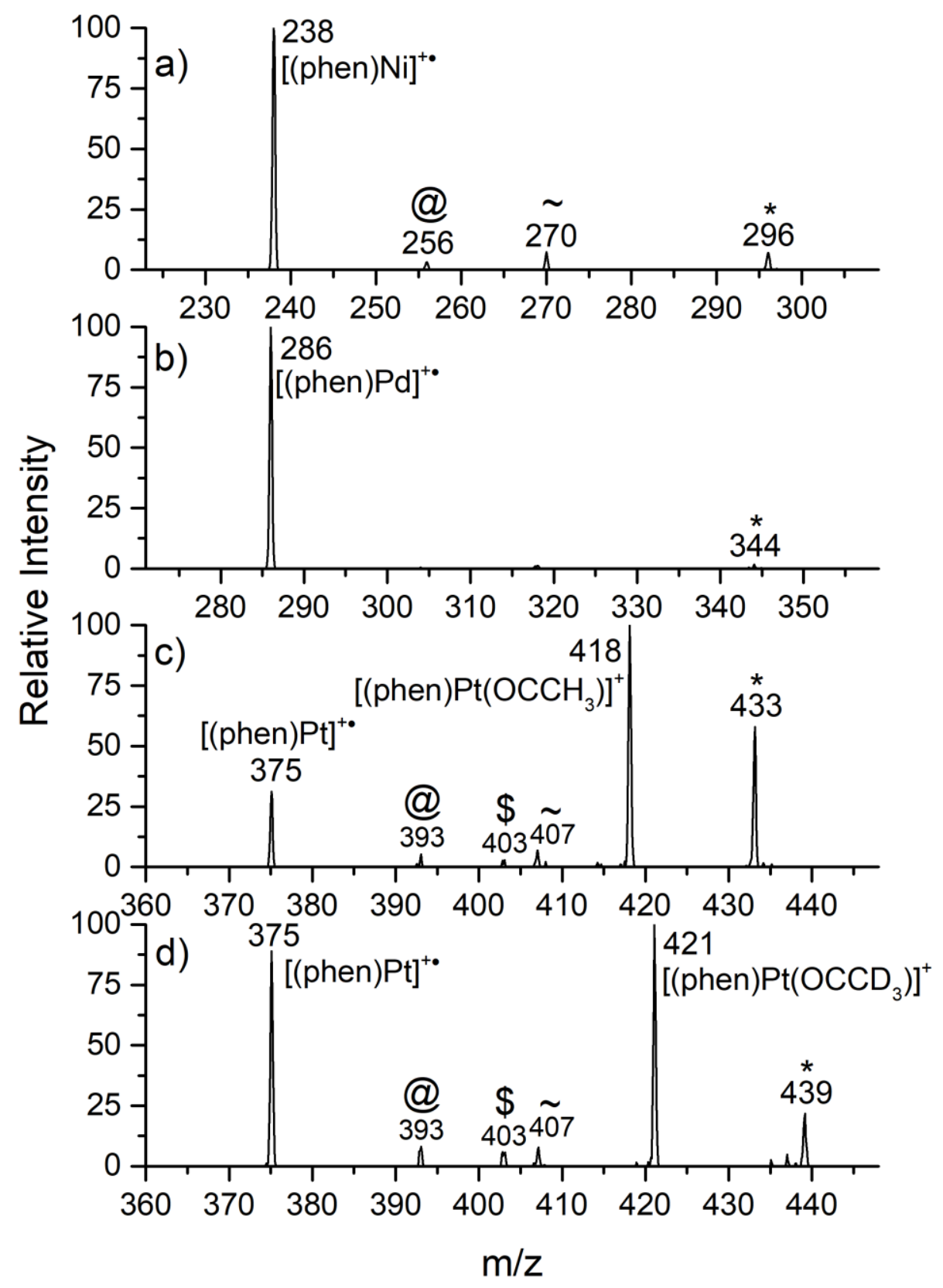

Fig. 5 LTQ MS ${ }^{5}$ spectra of mass-selected precursor ions, $\left[(\text { phen }) \mathrm{M}\left(\mathrm{OC}\left(\mathrm{CH}_{3}\right)_{2}\right)\right]^{+\bullet}$ undergoing CID at a normalized collision energy of 20 (arbitrary units) in the linear ion trap: (a) $\mathrm{M}=\mathrm{Ni}$; (b) $\mathrm{M}=$ Pd; and (c-d) M = Pt. The mass-selected precursor ions are designated by*,while @, \$ and are representing the water, the dinitrogen and the dioxygen adducts respectively (eq. 5) 


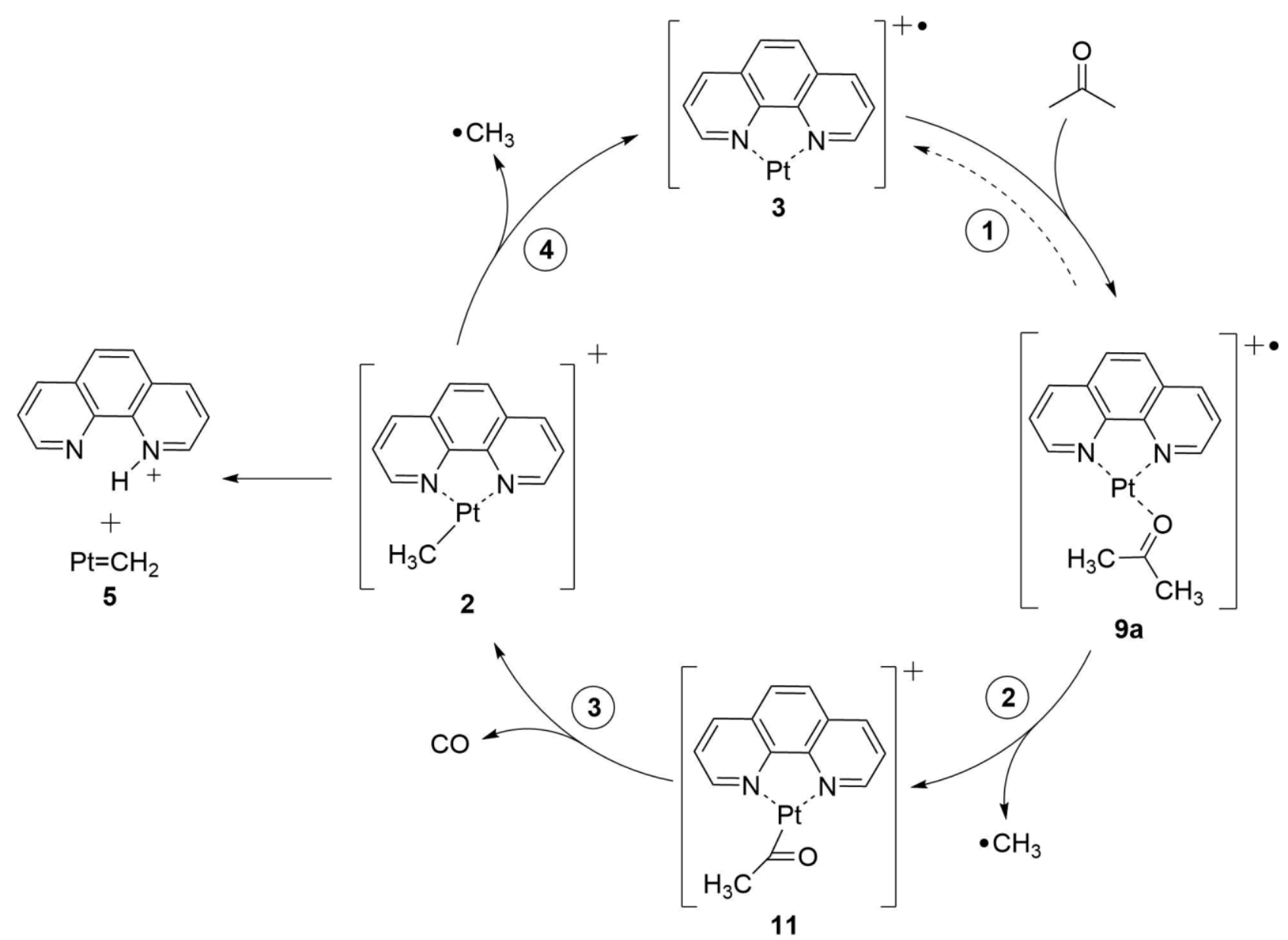

Scheme 1 Catalytic cycle for the decomposition of acetone

An examination of the catalytic cycle (Scheme 1) reveals that it suffers from the off cycle $\mathrm{Pt}=\mathrm{CH}_{2}$ loss (eq. 7) being the dominant pathway, with regeneration of the catalyst $\mathbf{3}$ being only a minor product in step 4. Nonetheless, DFT calculations were carried out to examine the energetics associated with all steps and the data is summarized in Table 3. Adduct formation is exothermic for step 1, consistent with the observation that this reaction occurs under the IMR conditions. Three different adducts $(\mathbf{9 a}-\mathbf{9 c})$ were located (Fig. 6b). For step 2 of the cycle, the transition state $\mathbf{T S}_{\mathbf{9} \mathbf{a}-\mathbf{1 0}}$ for activating the $\mathrm{C}-\mathrm{C}$ bond of acetone to form a methyl acyl intermediate $\left[(\text { phen }) \mathrm{Pt}\left(\mathrm{CH}_{3}\right)\left(\mathrm{OCCH}_{3}\right)\right]^{+}(\mathbf{1 0})$ is favored over the dissociation of the adduct to give $\mathbf{3}$ (Fig. 6). For the Pd and the Ni complexes, however, the formation of an acyl complex is disfavored both thermodynamically and kinetically, as the energies of the transition state and the acyl complex are higher than the energy needed for the dissociation of the adduct. The formation of the acyl complex 11 requires energy, which is delivered upon CID. However, the dissociation of the intermediate adduct(s) 9a-c via $\mathbf{T S}_{\mathbf{9} \text {-10 }}$ requires less energy than the formation of the acyl complex. The energy difference of $8 \mathrm{~kJ} \mathrm{~mol}^{-1}$ lies within the error of the functional used [65]. 


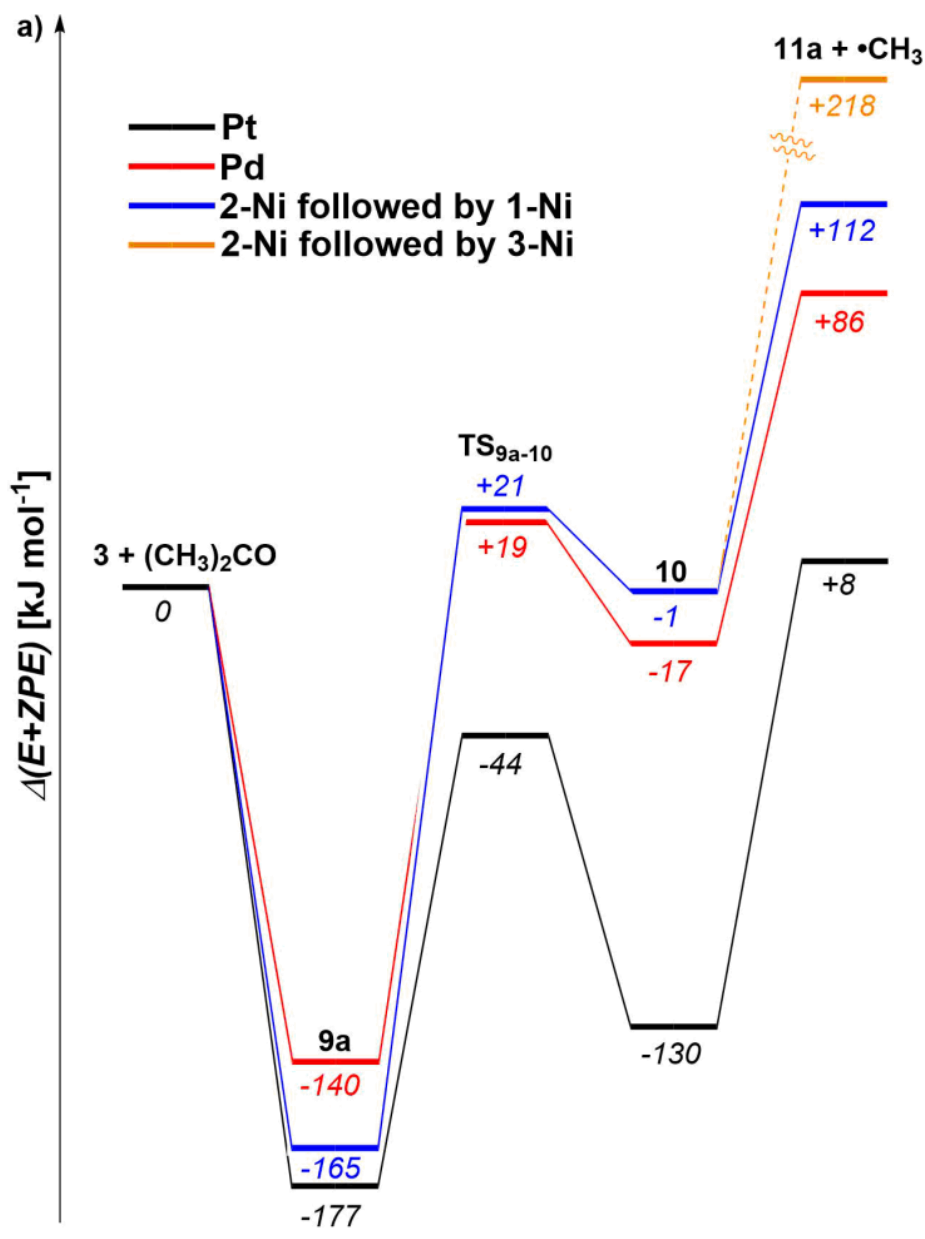


b)

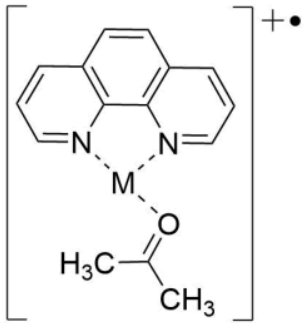

9a

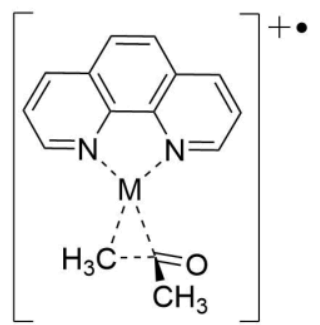

$\mathrm{TS}_{9 \mathrm{a}-10}$

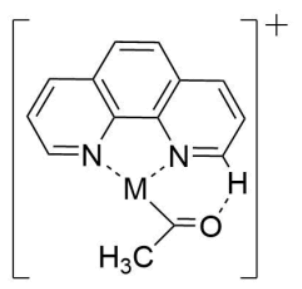

11b

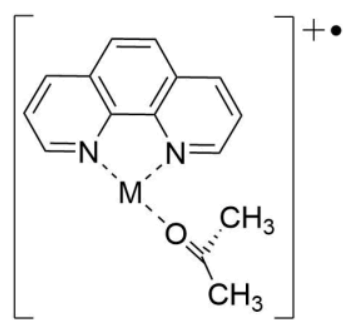

$9 b$

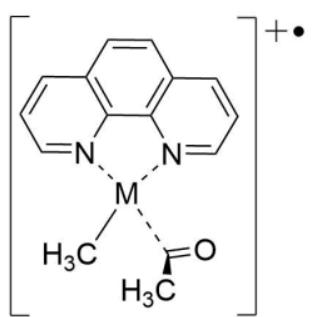

10

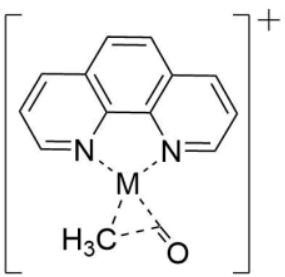

$\mathrm{TS}_{11 \mathrm{~b}-12}$

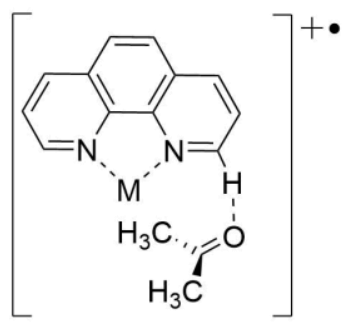

9c

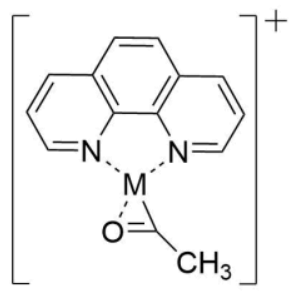

11a

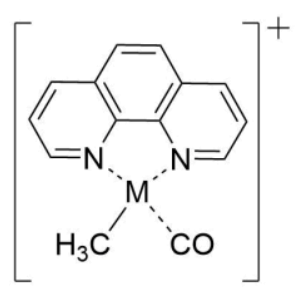

12

Fig. 6 DFT calculations at M06/SDD 6-31G(d) level of theory. (a) Plot of the potential energy diagram for acetone adduct formation and subsequent methyl loss for $\left[(\mathrm{phen}) \mathrm{M}\left(\mathrm{CH}_{3}\right)\right]^{+}$with $\mathrm{M}=2-$ Ni (followed by 1-Ni) (blue), 3-Ni (orange), Pd (red) and Pt (black); (b) Structures of key species 
The decarbonylation of $\mathbf{1 1}$ in step 3 to regenerate the methyl complex, [(phen) $\left.\operatorname{Pt}\left(\mathrm{CH}_{3}\right)\right]^{+}(\mathbf{2})$, and carbon monoxide requires $139 \mathrm{~kJ} \mathrm{~mol}^{-1}$ (Fig. S4), as found for the related decarbonylation of the bidentate enolate complex $\left[(\right.$ phen $) \operatorname{Pt}\left(\left(\mathrm{OC}\left(\mathrm{CH}_{2}\right) \mathrm{CH}_{3}\right)\right]^{+}[70]$. The transition state $\mathbf{T S} \mathbf{1 1 \mathbf { b } - \mathbf { 1 2 }}$ lies only $1 \mathrm{~kJ} \mathrm{~mol}^{-1}$ above the acyl complex $\mathbf{1 1 b}$, while the intermediate 12, in which CO is still coordinatively bound to the metal center, lies below $11 \mathbf{b}\left(-102 \mathrm{~kJ} \mathrm{~mol}^{-1}\right)$. Finally, the energetics associated with regeneration of the catalyst, 3, has already been discussed in detail in section 3.1 .

Table 3 DFT calculated reaction energetics of the catalytic cycle of the decomposition of acetone mediated by $\left[(\text { phen)Pt }]^{+\bullet}\right.$ with M06/SDD 6-31G(d) level of theory.

\begin{tabular}{|c|c|c|c|c|}
\hline $\begin{array}{c}\Delta(E+Z P E)[\mathrm{kJ} \\
\left.\text { mol }^{-1}\right]\end{array}$ & $\begin{array}{c}\text { Step 1 (formation } \\
\text { of adducts 9a }- \\
\text { 9c, eq. 8) }\end{array}$ & $\begin{array}{c}\text { Step 2 (Acyl } \\
\text { formation, eq. } \\
\text { 10) }\end{array}$ & Step 3 & Step 4 \\
\hline Isomer a & -177 & +185 & +155 & +258 \\
\hline Isomer b & -169 & +202 & $/$ & $/$ \\
\hline Isomer c & -91 & $/$ & $/$ & $/$ \\
\hline
\end{tabular}

\subsection{IMR with Allyl Iodide}

The IMR spectra of $\left[\left(\right.\right.$ phen) $\mathrm{M}^{+\bullet}$ with allyl iodide are given in Fig. 7. For all three metals Ni, Pd and Pt the formation of an allyl complex via allyl abstraction is observed (eq. 14). A previous report noted that $[(\text { phen }) \mathrm{Ni}]^{+\cdot}$ reacts via allyl abstraction as the major reaction together with the formation of minor product due to addition of allyl iodide [37]. For $\mathrm{M}=\mathrm{Pt}$ two further products could be observed: the iodo complex [(phen)Pt(I) $]^{+}$and the diiodoallyl complex $\left[(\text {phen }) \mathrm{Pt}(\mathrm{I})_{2}\left(\mathrm{CH}_{2} \mathrm{CHCH}_{2}\right)\right]^{+}$ (eqs. 15 and 16). The iodo complex also reacts with background gases to form the respective adducts (eq. 17). 


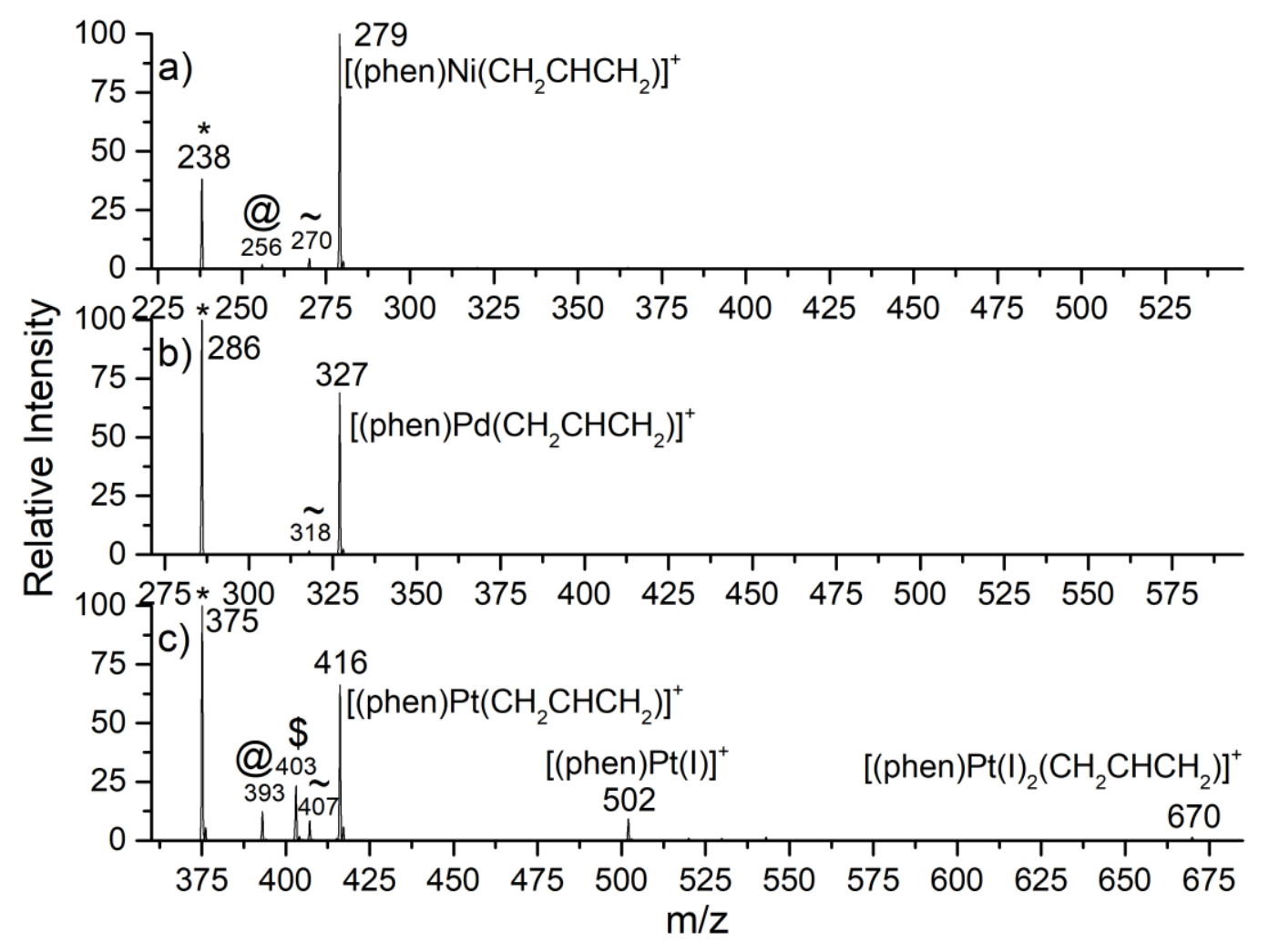

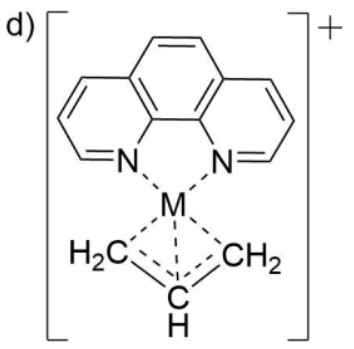

13

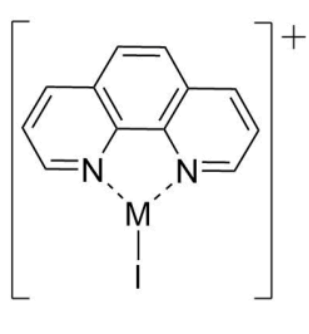

14

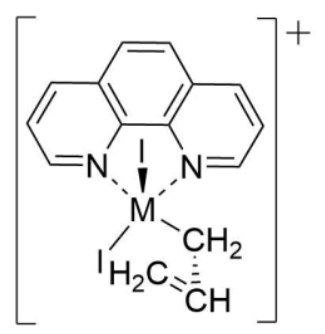

15

Fig. 7 (a-c) LTQ MS ${ }^{4}$ spectra of mass-selected precursor ions, [(phen)M $]^{+\bullet}$, undergoing IMR at an activation time of $30 \mathrm{~ms}$ with allyliodide in the linear ion trap (infusion rate $50 \mu \mathrm{L} / \mathrm{h}$ ): (a) $\mathrm{M}=\mathrm{Ni}$; (b) $\mathrm{M}=\mathrm{Pd}$; and (c) $\mathrm{M}=\mathrm{Pt}$. The mass-selected precursor ions are designated by *, while @, \$ and are representing the water, the dinitrogen and the dioxygen adducts respectively (eq. 5); (d) Structures of key species

$$
\begin{array}{llll}
{[(\text { phen }) \mathrm{M}]^{+\bullet}+} & \mathrm{CH}_{2} \mathrm{CHCH}_{2} \mathrm{I} & \rightarrow & {\left[(\text { phen }) \mathrm{M}\left(\mathrm{CH}_{2} \mathrm{CHCH}_{2}\right)\right]^{+}+\cdot \mathrm{I}(\mathrm{M}=\mathrm{Ni}, \mathrm{Pd})} \\
{[(\text { phen }) \mathrm{Pt}]^{+\bullet}+} & \mathrm{CH}_{2} \mathrm{CHCH}_{2} \mathrm{I} & \rightarrow & {[(\text { phen }) \mathrm{Pt}(\mathrm{I})]^{+}+\cdot \mathrm{CH}_{2} \mathrm{CHCH}_{2}} \\
{[(\text { phen }) \mathrm{Pt}(\mathrm{I})]^{+}+} & \mathrm{CH}_{2} \mathrm{CHCH}_{2} \mathrm{I} & \rightarrow & {\left[(\text { phen }) \mathrm{Pt}(\mathrm{I})_{2}\left(\mathrm{CH}_{2} \mathrm{CHCH}_{2}\right)\right]^{+}} \\
{[(\text {phen }) \operatorname{Pt}(\mathrm{I})]^{+}+} & \mathrm{L} & \rightarrow & {[(\text { phen }) \operatorname{Pt}(\mathrm{I})(\mathrm{L})]^{+}}
\end{array}
$$


The energetics of the observed reactions have been calculated (Fig. 7d, Table 4). The energetics of the three reactions giving $\mathbf{1 3}, \mathbf{1 4}$, and $\mathbf{1 5}$ are favored going down group 10 . The allyl abstraction is thermodynamically favored for each metal, whereas the iodine abstraction is only favored for platinum. The formation of $\left[(\text { phen }) \mathrm{M}(\mathrm{I})_{2}\left(\mathrm{CH}_{2} \mathrm{CHCH}_{2}\right)\right]^{+}$is favored for each metal, but can only be observed for platinum. This complex requires the formation of the iodo complex first, which is only favored for platinum. As calculated for the three-coordinate complex $\left[(\mathrm{phen}) \mathrm{Ni}\left(\mathrm{CH}_{3}\right)\right]^{+}$, the triplet state is more stable for the nickel complexes of 14 and $\mathbf{1 5}$. For 13, however, the singlet state is more stable than the triplet. The allyl ligand prefers to bind in a $\eta^{1}$ fashion for the triplet, whereas for the singlet the $\eta^{3}$ binding mode is preferred.

Table 4 DFT calculated reaction energetics for re the respective products of the reaction of $[(\text { phen }) \mathrm{M}]^{+\bullet}$ with allyl iodide with M06/SDD 6-31G(d) level of theory

\begin{tabular}{|c|c|c|c|}
\hline $\begin{array}{c}\Delta(E+Z P E)[\mathrm{kJ} \\
\left.\mathrm{mol}^{-1}\right]\end{array}$ & $\mathbf{1 3}$ & $\mathbf{1 4}$ & $\mathbf{1 5}$ \\
\hline $1-\mathrm{Ni}$ & -64 & +42 & -19 \\
\hline $3-\mathrm{Ni}$ & $+58^{(\mathrm{a})}$ & -3 & -52 \\
\hline $\mathrm{Pd}$ & -109 & +25 & -89 \\
\hline $\mathrm{Pt}$ & -202 & -69 & -217 \\
\hline
\end{tabular}

(a) Attempted optimization of a triplet structure in M06 led to spin annihilation, but was successfully carried out in B3LYP. The energetics were then obtained via single point energy calculations of this structure with M06/SDD 6-31G(d) level of theory

\section{Conclusion}

$\mathrm{MS}^{\mathrm{n}}$ experiments in a linear ion trap mass spectrometer readily yield the ligated group 10 metal complexes $[(\text { phen }) \mathrm{M}]^{+\bullet}$ in the formal oxidation state of +1 to allow their bimolecular reactivity to be explored. Of all the metals studied, Pt stands out in two of the reactions studied. In the fragmentation of $\left[(\text { phen }) \mathrm{Pt}\left(\mathrm{CH}_{3}\right)\right]^{+}$, the desired bond homolysis is only a minor pathway, while loss of the neutral carbene $\mathrm{Pt}=\mathrm{CH}_{2}$ dominates. The acetone adduct $\left[(\text { phen }) \mathrm{Pt}\left(\mathrm{OC}\left(\mathrm{CH}_{3}\right)_{2}\right)\right]^{+\bullet}$ fragments via methyl radical loss to form the coordinated acyl complex, [(phen) $\left.\mathrm{Pt}\left(\mathrm{OCCH}_{3}\right)\right]^{+}$, a reaction that is unique for Pt. It will be interesting to explore the gas-phase formation and reactivity of other $[(\mathrm{L}) \mathrm{M}]^{+\bullet}$ complexes in which the ligand, L, exerts different geometrical and electronic effects to phen. One class of ligands that would be particularly interesting are phosphine based ligands. Previous studies suggest that alternative "synthetic" strategies to CID of carboxylate complexes are required, since decarbonylation rather than decarboxylation occurs for $\left[\mathrm{CH}_{3} \mathrm{CO}_{2} \mathrm{Pd}\left(\left(\mathrm{PPh}_{2}\right)_{2} \mathrm{CH}_{2}\right)\right]^{+}$[71]. Given the widespread 
success of photoactivated C-I bond homolysis [72] and that Pd-azide bonds in $\mathrm{Pd}(\mathrm{II})$ complexes are known to undergo photoactivated bond homolysis [73], we are exploring whether related M-X photoactivated bond homolysis could be used to prepare $[(\mathrm{L}) \mathrm{M}]^{+\bullet}$ from suitable precursors.

\section{Acknowledgment}

We thank the Australian Research Council for financial support DP180101187 (to RAJO and AJC). The authors gratefully acknowledge the generous allocation of computing time from the University of Tasmania and the National Computing Infrastructure (fz2). We thank the DAAD (ISAP program) for funding an exchange program between the Schools of Chemistry of HumboldtUniversität zu Berlin and The University of Melbourne. KG is grateful to the "Fondation Félix Chomé" for the "Bourse Chomé-Bastian" scholarship.

\section{References}

1. Johansson Seechurn, C.C.C., Kitching, M.O., Colacot, T.J., Snieckus, V.: Palladium-catalyzed cross-coupling: a historical contextual perspective to the 2010 Nobel Prize. Angew. Chem. Int. Ed. 21, 5062-5085 (2012)

2. Bonney, K.J., Schoenebeck, F.: Experiment and computation: a combined approach to study the reactivity of palladium complexes in oxidation states 0 to IV. Chem. Soc. Rev. 18, 66096638 (2014)

3. Ananikov, V.P., Zelinsky, N.D.: Nickel: The "Spirited Horse" of Transition Metal Catalysis. ACS Catal. 3, 1964-1971 (2015)

4. Lin, C.-Y., Power, P.P.: Complexes of $\mathrm{Ni}(\mathrm{i}):$ a "rare" oxidation state of growing importance. Chem. Soc. Rev. 17, 5347-5399 (2017)

5. Balch, A.L.: Odd Oxidation States of Palladium and Platinum. Comments Inorganic Chem. 2-3, 51-67 (1984)

6. Simpson, Q., Sinclair, M.J.G., Lupton, D.W., Chaplin, A.B., Hooper, J.F.: Oxidative CrossCoupling of Boron and Antimony Nucleophiles via Palladium(I). Org. Lett. 18, 5537-5540 (2018)

7. Zuo, Z., Ahneman, D.T., Chu, L., Terrett, J.A., Doyle, A.G., MacMillan, D.W.C.: Dual catalysis. Merging photoredox with nickel catalysis: coupling of $\alpha$-carboxyl $\mathrm{sp}^{3}$-carbons with aryl halides. Science 6195, 437-440 (2014)

8. Tellis, J.C., Kelly, C.B., Primer, D.N., Jouffroy, M., Patel, N.R., Molander, G.A.: Single-Electron Transmetalation via Photoredox/Nickel Dual Catalysis: Unlocking a New Paradigm for $\mathrm{sp}^{3}-\mathrm{sp}^{2}$ Cross-Coupling. Acc. Chem. Res. 7, 1429-1439 (2016)

9. Matsui, J.K., Lang, S.B., Heitz, D.R., Molander, G.A.: Photoredox-Mediated Routes to Radicals: The Value of Catalytic Radical Generation in Synthetic Methods Development. ACS Catal. 4, 2563-2575 (2017)

10. Mó, O., Yáñez, M., Salpin, J.-Y., Tortajada, J.: Thermochemistry, bonding, and reactivity of $\mathrm{Ni}^{+}$ and $\mathrm{Ni}^{2+}$ in the gas phase. Mass Spectrom. Rev. 4, 474-516 (2007) 
11. O'Hair, R.A.J.: Mass spectrometry based studies of gas phase metal catalyzed reactions. Int. J. Mass Spectrom., 121-129 (2015)

12. Eller, K., Schwarz, H.: Organometallic chemistry in the gas phase. Chem. Rev. 6, 1121-1177 (1991)

13. Böhme, D.K., Schwarz, H.: Gas-phase catalysis by atomic and cluster metal ions: the ultimate single-site catalysts. Angew. Chem. Int. Ed. 16, 2336-2354 (2005)

14. Schwarz, H.: Ménage-à-trois: single-atom catalysis, mass spectrometry, and computational chemistry. Catal. Sci. Technol. 19, 4302-4314 (2017)

15. Schwarz, H.: Chemistry with methane: concepts rather than recipes. Angew. Chem. Int. Ed. 43, 10096-10115 (2011)

16. Schwarz, H.: How and Why Do Cluster Size, Charge State, and Ligands Affect the Course of Metal-Mediated Gas-Phase Activation of Methane? Isr. J. Chem. 10, 1413-1431 (2014)

17. Schwarz, H.: Remote functionalization of $\mathrm{C}-\mathrm{H}$ and $\mathrm{C}-\mathrm{C}$ bonds by "naked" transition-metal ions (Cosi Fan Tutte). Acc. Chem. Res. 8, 282-287 (1989)

18. Schröder, D., Shaik, S., Schwarz, H.: Two-State Reactivity as a New Concept in Organometallic Chemistry. Acc. Chem. Res. 3, 139-145 (2000)

19. Vikse, K.L., Mclndoe, J.S.: Mechanistic insights from mass spectrometry: examination of the elementary steps of catalytic reactions in the gas phase. Pure Appl. Chem. 4, 361-377 (2015)

20. Vikse, K.L., Ahmadi, Z., Scott McIndoe, J.: The application of electrospray ionization mass spectrometry to homogeneous catalysis. Coord. Chem. Rev., 96-114 (2014)

21. Heinemann, C., Wesendrup, R., Schwarz, H.: Pt'-mediated activation of methane: theory and experiment. Chem. Phys. Lett. 1-3, 75-83 (1995)

22. Božović, A., Feil, S., Koyanagi, G.K., Viggiano, A.A., Zhang, X., Schlangen, M., Schwarz, H., Bohme, D.K.: Conversion of methane to methanol: nickel, palladium, and platinum $\left(d^{9}\right)$ cations as catalysts for the oxidation of methane by ozone at room temperature. Chem. Eur. J. 38, 11605-11610 (2010)

23. Georgiadis, R., Fisher, E.R., Armentrout, P.B.: Neutral and ionic metal-hydrogen and metalcarbon bond energies: reactions of cobalt, nickel, and copper with ethane, propane, methylpropane, and dimethylpropane. J. Am. Chem. Soc. 12, 4251-4262 (1989)

24. van Koppen, P.A.M., Bowers, M.T., Fisher, E.R., Armentrout, P.B.: Relative Energetics of C-H and $\mathrm{C}-\mathrm{C}$ Bond Activation of Alkanes: Reactions of $\mathrm{Ni}^{+}$and $\mathrm{Fe}^{+}$with Propane on the Lowest Energy (Adiabatic) Potential Energy Surfaces. J. Am. Chem. Soc. 9, 3780-3791 (1994)

25. Zhang, X.-G., Liyanage, R., Armentrout, P.B.: Potential Energy Surface for Activation of Methane by $\mathrm{Pt}^{+}$: A Combined Guided Ion Beam and DFT Study. J. Am. Chem. Soc. 23, 55635575 (2001)

26. Mansell, A., Theis, Z., Gutierrez, M.G., Faza, O.N., Lopez, C.S., Bellert, D.J.: Submerged Barriers in the $\mathrm{Ni}^{+}$Assisted Decomposition of Propionaldehyde. J. Phys. Chem. A 15, 2275-2284 (2016)

27. Robinson, P.S.D., Khairallah, G.N., da Silva, G., Lioe, H., O'Hair, R.A.J.: Gold-mediated C-I bond activation of iodobenzene. Angew. Chem. Int. Ed. 16, 3812-3817 (2012)

28. Luman, C.R., Castellano, F.N.: Phenanthroline Ligands. In: McCleverty, J.A., Meyer, T.J. (eds.) Comprehensive Coordination Chemistry II, pp. 25-39. Elsevier, Amsterdam (2003)

29. O'Hair, R.A.J., Rijs, N.J.: Gas phase studies of the Pesci decarboxylation reaction: synthesis, structure, and unimolecular and bimolecular reactivity of organometallic ions. Acc. Chem. Res. 2, 329-340 (2015)

30. Woolley, M.J., Khairallah, G.N., Donnelly, P.S., O'Hair, R.A.J.: Nitrogen adduction by three coordinate group 10 organometallic cations: platinum is favoured over nickel and palladium. Rapid Commun. Mass Spectrom. 14, 2083-2088 (2011) 
31. Woolley, M., Ariafard, A., Khairallah, G.N., Kwan, K.H.-Y., Donnelly, P.S., White, J.M., Canty, A.J., Yates, B.F., O'Hair, R.A.J.: Decarboxylative-coupling of allyl acetate catalyzed by group 10 organometallics, (phen) $\mathrm{M}\left(\mathrm{CH}_{3}\right)^{+}$. J. Org. Chem. 24, 12056-12069 (2014)

32. Woolley, M.J., Khairallah, G.N., da Silva, G., Donnelly, P.S., Yates, B.F., O'Hair, R.A.J.: Role of the Metal, Ligand, and Alkyl/Aryl Group in the Hydrolysis Reactions of Group 10 Organometallic Cations [(L)M(R)] ${ }^{+}$. Organometallics 23, 6931-6944 (2013)

33. Woolley, M., Khairallah, G.N., da Silva, G., Donnelly, P.S., O'Hair, R.A.J.: Direct versus WaterMediated Protodecarboxylation of Acetic Acid Catalyzed by Group 10 Carboxylates, [(phen) $\left.\mathrm{M}\left(\mathrm{O}_{2} \mathrm{CCH}_{3}\right)\right]^{+}$. Organometallics 19, 5185-5197 (2014)

34. Noor, A., Li, J., Khairallah, G.N., Li, Z., Ghari, H., Canty, A.J., Ariafard, A., Donnelly, P.S., O'Hair, R.A.J.: A one-pot route to thioamides discovered by gas-phase studies: palladium-mediated $\mathrm{CO}_{2}$ extrusion followed by insertion of isothiocyanates. Chem. Commun. 27, 3854-3857 (2017)

35. Yang, Y., Noor, A., Canty, A.J., Ariafard, A., Donnelly, P.S., O'Hair, R.A.J.: Synthesis of Amidines by Palladium-Mediated $\mathrm{CO}_{2}$ Extrusion Followed by Insertion of Carbodiimides: Translating Mechanistic Studies to Develop a One-Pot Method. Organometallics (2018)

36. Zhugralin, A.R., Kobylianskii, I.J., Chen, P.: Experimental Gas-Phase and in Silico Investigation of $\beta$-Methyl Elimination from Cationic Palladium Alkyl Species. Organometallics 7, 1301-1306 (2015)

37. Parker, M.L., Gronert, S.: Investigating reduced metal species via sequential ion/ion and ion/molecule reactions: The reactions of transition metal phenanthrolines with allyl iodide. Int. J. Mass Spectrom., 73-78 (2017)

38. Price, J.H., Williamson, A.N., Schramm, R.F., Wayland, B.B.: Palladium(II) and platinum(II) alkyl sulfoxide complexes. Examples of sulfur-bonded, mixed sulfur- and oxygen-bonded, and totally oxygen-bonded complexes. Inorg. Chem. 6, 1280-1284 (1972)

39. Fanizzi, F.P., Natile, G., Lanfranchi, M., Tiripicchio, A., Laschi, F., Zanello, P.: Steric Crowding and Redox Reactivity in Platinum(II) and Platinum(IV) Complexes Containing Substituted 1,10Phenanthrolines. Inorg. Chem. 11, 3173-3182 (1996)

40. Soro, B., Stoccoro, S., Minghetti, G., Zucca, A., Cinellu, M.A., Gladiali, S., Manassero, M., Sansoni, M.: Synthesis of the First C-2 Cyclopalladated Derivatives of 1,3-Bis(2-

pyridyl)benzene. Crystal Structures of $[\mathrm{Hg}(\mathrm{N}-\mathrm{C}-\mathrm{N}) \mathrm{Cl}],[\mathrm{Pd}(\mathrm{N}-\mathrm{C}-\mathrm{N}) \mathrm{Cl}]$, and $\left[\mathrm{Pd}_{2}(\mathrm{~N}-\mathrm{C}-\mathrm{N})_{2}(\mu-\mathrm{OAC})\right]_{2}$ $\left[\mathrm{Hg}_{2} \mathrm{Cl}_{6}\right]$. Catalytic Activity in the Heck Reaction. Organometallics 1, 53-61 (2005)

41. Donald, W.A., McKenzie, C.J., O'Hair, R.A.J.: C-H bond activation of methanol and ethanol by a high-spin Fe IV O biomimetic complex. Angew. Chem. Int. Ed. 36, 8379-8383 (2011)

42. Lam, A.K.Y., Li, C., Khairallah, G., Kirk, B.B., Blanksby, S.J., Trevitt, A.J., Wille, U., O'Hair, R.A.J., da Silva, G.: Gas-phase reactions of aryl radicals with 2-butyne: experimental and theoretical investigation employing the N-methyl-pyridinium-4-yl radical cation. Phys. Chem. Chem. Phys. 7, 2417-2426 (2012)

43. Donald, W.A., Khairallah, G.N., O'Hair, R.A.J.: The effective temperature of ions stored in a linear quadrupole ion trap mass spectrometer. J. Am. Soc. Mass Spectrom. 6, 811-815 (2013)

44. Gaussian 09, Revision D.01, M. J. Frisch, G. W. Trucks, H. B. Schlegel, G. E. Scuseria, M. A. Robb, J. R. Cheeseman, G. Scalmani, V. Barone, G. A. Petersson, H. Nakatsuji, X. Li, M.

Caricato, A. Marenich, J. Bloino, B. G. Janesko, R. Gomperts, B. Mennucci, H. P. Hratchian, J. V. Ortiz, A. F. Izmaylov, J. L. Sonnenberg, D. Williams-Young, F. Ding, F. Lipparini, F. Egidi, J.

Goings, B. Peng, A. Petrone, T. Henderson, D. Ranasinghe, V. G. Zakrzewski, J. Gao, N. Rega, G. Zheng, W. Liang, M. Hada, M. Ehara, K. Toyota, R. Fukuda, J. Hasegawa, M. Ishida, T. Nakajima, Y. Honda, O. Kitao, H. Nakai, T. Vreven, K. Throssell, J. A. Montgomery, Jr., J. E. 
Peralta, F. Ogliaro, M. Bearpark, J. J. Heyd, E. Brothers, K. N. Kudin, V. N. Staroverov, T. Keith, R. Kobayashi, J. Normand, K. Raghavachari, A. Rendell, J. C. Burant, S. S. Iyengar, J. Tomasi, M. Cossi, J. M. Millam, M. Klene, C. Adamo, R. Cammi, J. W. Ochterski, R. L. Martin, K. Morokuma, O. Farkas, J. B. Foresman, and D. J. Fox, Gaussian, Inc., Wallingford CT, 2016.

45. Zhao, Y., Truhlar, D.G.: The M06 suite of density functionals for main group thermochemistry, thermochemical kinetics, noncovalent interactions, excited states, and transition elements: two new functionals and systematic testing of four M06-class functionals and 12 other functionals. Theor. Chem. Acc. 1-3, 215-241 (2008)

46. Andrae, D., Huermann, U., Dolg, M., Stoll, H., Preu, H.: Energy-adjusted ab initio pseudopotentials for the second and third row transition elements. Theoret. Chim. Acta 2, 123-141 (1990)

47. Dolg, M., Wedig, U., Stoll, H., Preuss, H.: Energy-adjusted ab initio pseudopotentials for the first row transition elements. J. Chem. Phys. 2, 866-872 (1987)

48. Petersson, G.A., Al-Laham, M.A.: A complete basis set model chemistry. II. Open-shell systems and the total energies of the first-row atoms. J. Chem. Phys. 9, 6081-6090 (1991)

49. Gaussian 16, Revision B.01, M. J. Frisch, G. W. Trucks, H. B. Schlegel, G. E. Scuseria, M. A. Robb, J. R. Cheeseman, G. Scalmani, V. Barone, G. A. Petersson, H. Nakatsuji, X. Li, M. Caricato, A. V. Marenich, J. Bloino, B. G. Janesko, R. Gomperts, B. Mennucci, H. P. Hratchian, J. V. Ortiz, A. F. Izmaylov, J. L. Sonnenberg, D. Williams-Young, F. Ding, F. Lipparini, F. Egidi, J. Goings, B. Peng, A. Petrone, T. Henderson, D. Ranasinghe, V. G. Zakrzewski, J. Gao, N. Rega, G. Zheng, W. Liang, M. Hada, M. Ehara, K. Toyota, R. Fukuda, J. Hasegawa, M. Ishida, T. Nakajima, Y. Honda, O. Kitao, H. Nakai, T. Vreven, K. Throssell, J. A. Montgomery, Jr., J. E. Peralta, F. Ogliaro, M. J. Bearpark, J. J. Heyd, E. N. Brothers, K. N. Kudin, V. N. Staroverov, T. A. Keith, R. Kobayashi, J. Normand, K. Raghavachari, A. P. Rendell, J. C. Burant, S. S. lyengar, J. Tomasi, M. Cossi, J. M. Millam, M. Klene, C. Adamo, R. Cammi, J. W. Ochterski, R. L. Martin, K. Morokuma, O. Farkas, J. B. Foresman, and D. J. Fox, Gaussian, Inc., Wallingford CT, 2016.

50. Becke, A.D.: Density-functional thermochemistry. III. The role of exact exchange. J. Chem. Phys. 7, 5648-5652 (1993)

51. Grimme, S., Antony, J., Ehrlich, S., Krieg, H.: A consistent and accurate ab initio parametrization of density functional dispersion correction (DFT-D) for the 94 elements $\mathrm{H}-\mathrm{Pu}$. J. Chem. Phys. 15, 154104 (2010)

52. Grimme, S., Ehrlich, S., Goerigk, L.: Effect of the damping function in dispersion corrected density functional theory. J. Comput. Chem. 7, 1456-1465 (2011)

53. McLean, A.D., Chandler, G.S.: Contracted Gaussian basis sets for molecular calculations. I. Second row atoms, $Z=11-18$. J. Chem. Phys. 10, 5639-5648 (1980)

54. Neese, F.: Software update: the ORCA program system, version 4.0. WIREs Comput. Mol. Sci. 1, e1327 (2018)

55. Chai, J.-D., Head-Gordon, M.: Long-range corrected hybrid density functionals with damped atom-atom dispersion corrections. Phys. Chem. Chem. Phys. 44, 6615-6620 (2008)

56. Goerigk, L., Grimme, S.: Efficient and Accurate Double-Hybrid-Meta-GGA Density FunctionalsEvaluation with the Extended GMTKN30 Database for General Main Group Thermochemistry, Kinetics, and Noncovalent Interactions. J. Chem. Theory Comput. 2, 291-309 (2011)

57. Kozuch, S., Martin, J.M.L.: DSD-PBEP86: in search of the best double-hybrid DFT with spincomponent scaled MP2 and dispersion corrections. Phys. Chem. Chem. Phys. 45, 2010420107 (2011)

58. Weigend, F., Häser, M., Patzelt, H., Ahlrichs, R.: RI-MP2: optimized auxiliary basis sets and demonstration of efficiency. Chem. Phys. Lett. 1-3, 143-152 (1998) 
59. Weigend, F., Ahlrichs, R.: Balanced basis sets of split valence, triple zeta valence and quadruple zeta valence quality for $\mathrm{H}$ to $\mathrm{Rn}$ : Design and assessment of accuracy. Phys. Chem. Chem. Phys. 18, 3297-3305 (2005)

60. Mehta, N., Casanova-Páez, M., Goerigk, L.: Semi-empirical or non-empirical double-hybrid density functionals: which are more robust? Phys. Chem. Chem. Phys. 36, 23175-23194 (2018)

61. McLuckey, S.A., Goeringer, D.E.: Slow Heating Methods in Tandem Mass Spectrometry. J. Mass Spectrom. 5, 461-474 (1997)

62. Dau, P.D., Armentrout, P.B., Michelini, M.C., Gibson, J.K.: Activation of carbon dioxide by a terminal uranium-nitrogen bond in the gas-phase: a demonstration of the principle of microscopic reversibility. Phys. Chem. Chem. Phys. 10, 7334-7340 (2016)

63. Butschke, B., Schwarz, H.: Mechanistic Study on the Gas-Phase Generation of "Rollover"Cyclometalated [M(bipy-H) $]^{+}(\mathrm{M}=\mathrm{Ni}, \mathrm{Pd}, \mathrm{Pt})$. Organometallics 22, 6002-6011 (2010)

64. Perera, M., Metz, R.B., Kostko, O., Ahmed, M.: Vacuum Ultraviolet Photoionization Studies of $\mathrm{PtCH}_{2}$ and $\mathrm{H}-\mathrm{Pt}-\mathrm{CH}_{3}$ : A Potential Energy Surface for the $\mathrm{Pt}+\mathrm{CH}_{4}$ Reaction. Angew. Chem. Int. Ed. 3, 922-925 (2013)

65. Goerigk, L., Hansen, A., Bauer, C., Ehrlich, S., Najibi, A., Grimme, S.: A look at the density functional theory zoo with the advanced GMTKN55 database for general main group thermochemistry, kinetics and noncovalent interactions. Phys. Chem. Chem. Phys. 48, 3218432215 (2017)

66. Bruin, B. de, Gualco, P., Paul, N.D.: Redox Non-innocent Ligands. In: Stradiotto, M., Lundgren, R.J. (eds.) Ligand Design in Metal Chemistry, vol. 33, pp. 176-204. John Wiley \& Sons, Ltd, Chichester, UK (2016)

67. Gómez-Gallego, M., Sierra, M.A.: Kinetic isotope effects in the study of organometallic reaction mechanisms. Chem. Rev. 8, 4857-4963 (2011)

68. Yu, D., Tian, Z.-Y., Wang, Z., Liu, Y.-X., Zhou, L.: Experimental and theoretical study on acetone pyrolysis in a jet-stirred reactor. Fuel, 1380-1387 (2018)

69. Trentelman, K.A., Kable, S.H., Moss, D.B., Houston, P.L.: Photodissociation dynamics of acetone at $193 \mathrm{~nm}$ : Photofragment internal and translational energy distributions. J. Chem. Phys. 12, 7498-7513 (1989)

70. Greis, K., Canty, A.J., O'Hair, R.A.J.: Gas-Phase Reactions of the Group 10 Organometallic Cations, [(phen) $\left.\mathrm{M}\left(\mathrm{CH}_{3}\right)\right]^{+}$with Acetone: Only Platinum Promotes a Catalytic Cycle via the Enolate [(phen) $\left.\mathrm{Pt}\left(\mathrm{OC}\left(\mathrm{CH}_{2}\right) \mathrm{CH}_{3}\right)\right]^{+}$. Z. Phys. Chem., in press, DOI: https://doi.org/10.1515/zpch2018-1355

71. Lesslie, M., Yang, Y., Canty, A.J., Piacentino, E., Berthias, F., Maitre, P., Ryzhov, V., O'Hair, R.A.J.: Ligand-induced decarbonylation in diphosphine-ligated palladium acetates $\mathrm{CH}_{3} \mathrm{CO}_{2} \mathrm{Pd}\left(\left(\mathrm{PR}_{2}\right)_{2} \mathrm{CH}_{2}\right)^{+}$( $\mathrm{R}=\mathrm{Me}$ and $\left.\mathrm{Ph}\right)$. Chem. Commun. 4, 346-349 (2018)

72. Ly, T., Julian, R.R.: Residue-specific radical-directed dissociation of whole proteins in the gas phase. J. Am. Chem. Soc. 1, 351-358 (2008)

73. Knoll, H., Stich, R., Hennig, H., Stufkens, D.J.: Spectroscopic studies on the mechanism of photolysis of $\mathrm{Pt}\left(\mathrm{N}_{3}\right)_{2}\left(\mathrm{P}\left(\mathrm{C}_{6} \mathrm{H}_{5}\right)_{3}\right)_{2}$. Inorg. Chim. Acta 1, 71-76 (1990) 
TOC graphic (JASMS dimensions are $8 \mathrm{~cm}$ (3.15 inches) wide x $4 \mathrm{~cm}$ (1.57 inches) high):

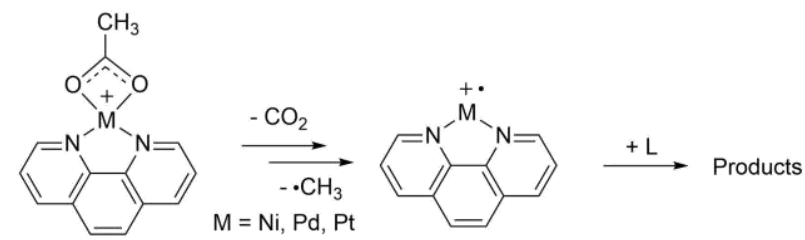

formation of metal complexes reactivity explored for $\mathrm{L}=\mathrm{O}_{2}, \mathrm{~N}_{2}$,

\begin{tabular}{|c|c|}
\hline in +1 oxidation state & $\mathrm{H}_{2} \mathrm{O},\left(\mathrm{CH}_{3}\right)_{2} \mathrm{CO}$ and $\mathrm{CH}_{2}=\mathrm{CHCH}_{2} \mathrm{I}$ \\
\hline favored for $\mathrm{Ni}$ and $\mathrm{Pd}$ & $\begin{array}{l}\text { Pt promotes unique bond } \\
\text { homolysis for acetone }\end{array}$ \\
\hline
\end{tabular}

